\title{
Biology and Biotechnology Research Program Overview and Highlights
}

March, 2003

Berthold W. Weinstein, Associate Director (Acting)

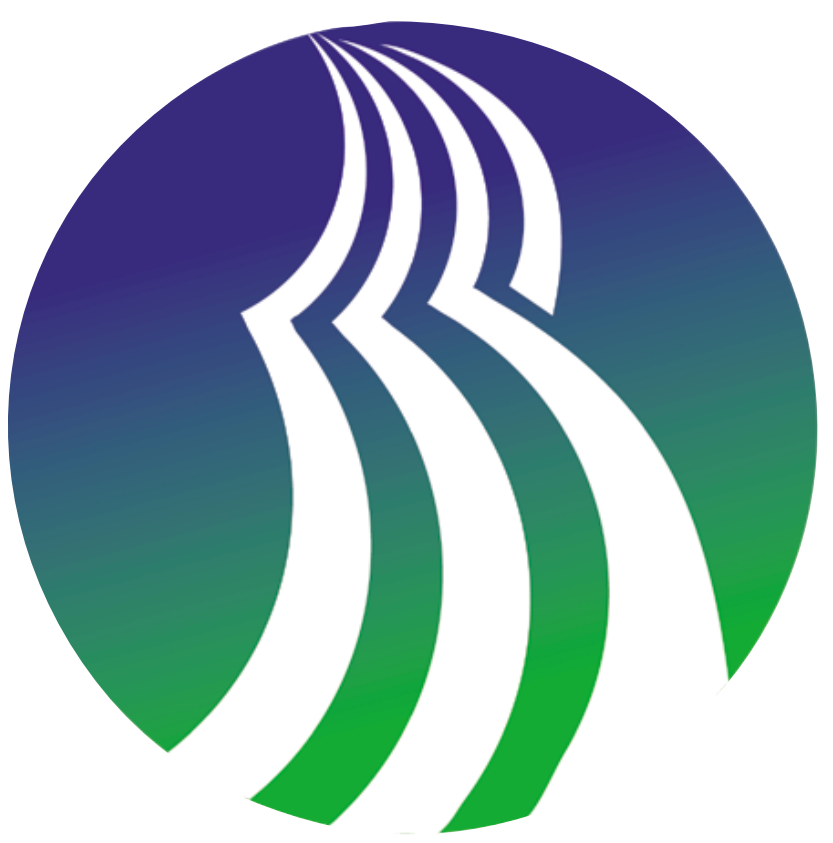

Lawrence Livermore National Laboratory Livermore, CA 94551 



\section{Biology and Biotechnology Research Program \\ Overview and Highlights}

March, 2003

Lawrence Livermore National Laboratory

Livermore, CA 94551 
For additional information regarding the Biology and Biotechnology Research Program, visit the following webpage on the Internet:

http://greengenes.llnl.gov/bbrp/bbrp.homepage.html

or contact:

Ms. Peggy Biggs

Biology and Biotechnology Research Program

Lawrence Livermore National Laboratory

PO Box 808, L-452

Livermore, CA 94551

Ph: 925-423-9433 Fax: 925-422-2282

biggs2@1lnl.gov

UCRL-ID-152025

Work performed under the auspices of the U.S. Department of Energy by the Lawrence Livermore National Laboratory under contract number W-7405-ENG-48. Overview and Highlights editor: Christa K. Prange (prange1@1lnl.gov).

Disclaimer:

This document was prepared as an account of work sponsored by an agency of the United States Government. Neither the United States Government nor the University of California nor any of the their employees makes any warranty, express or implied, or assumes any legal liability or responsibility for the accuracy, completeness, or usefulness of any information, apparatus, product, or process disclosed, or represents that its use would not infringe privately owned rights. Reference herein to any specific commercial products, process, or service by trade name, trademark, manufacturer, or otherwise, does not necessarily constitute or employ its endorsement, recommendation, or favoring by the United States Government of the University of California. The views and opinions of authors expressed herein do not necessarily state or reflect those of the United States Government or the University of California, and shall not be used for advertising or product endorsement purposes. 


\section{TABLE OF CONTENTS}

Mission Statement............................................................................................3

\subsection{Research Areas, Relevance and Achievements...............................4}

Research Areas........................................................................................................................4

Biodefense Division

Computational and Systems Biology Division

Genome Biology Division

Health Effects Genetics Division

Molecular Biophysics Division

Environmental Microbiology Group

Bioinformatics Group

Physical Biosciences Institute

Abstracts......................................................................................................................

Significant Achievements.....................................................................................................36

Genome Biology

Biodefense

Molecular Biophysics

DNA repair

Mutagenesis and carcinogenesis

Genetic Susceptibility

Reproductive and Developmental Biology

Radionuclide and Radiation Biology

Computational and Systems Biology

Bioinformatics

2.0 Program Organization, Facilities and Resources...........................47

Organizational Structure......................................................................................................47

Program Reviews and Advisory Committee.................................................................49

Budget Information..........................................................................................................50

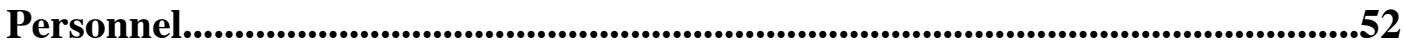

Facilities......................................................................................................................54

Compliance with Federal Regulations...............................................................................55

3.0 Appendices......................................................................................................56

I. Senior Staff Listing.............................................................................................56

II. Staff Extramural Activities..........................................................................................58

III. Publications, Citations and other Information Transfer...............................67

IV. Patents and Invention Disclosures.......................................................................75

V. Funding Information.......................................................................................................77 


\section{BIOLOGY AND BIOTECHNOLOGY RESEARCH PROGRAM February, 2003}

\section{Enhancing the nation's health and security through technological innovation in the biosciences}

\section{Our Mission}

LLNL conducts multidisciplinary bioscience to fill national needs. Our primary roles are to:

- develop knowledge and tools which enhance national security, including biological, chemical and nuclear capabilities, and energy and environmental security

- develop understanding of genetic and biochemical processes to enhance disease prevention, detection and treatment

- develop unique biochemical measurement and computational modeling capabilities which enable understanding of biological processes

- develop technology and tools which enhance healthcare

We execute our roles through integrated multidisciplinary programs that apply our competencies in:

- microbial and mammalian genomics - the characterization of DNA, the genes it encodes, their regulation and function and their role in living systems

- protein function and biochemistry - the structure, function, and interaction of proteins and other molecules involved in the integrated biochemical function of the processes of life

- computational modeling and understanding of biochemical systems - the application of high-speed computing technology to simulate and visualize complex, integrated biological processes

- bioinformatics - databasing, networking, and analysis of biological data

- bioinstrumentation - the application of physical and engineering technologies to novel biological and biochemical measurements, laboratory automation, medical device development, and healthcare technologies

We leverage the Laboratory's exceptional capabilities in the physical, computational, chemical, environmental and engineering sciences.

We partner with industry and universities to utilize their state-of-the art technology and science and to make our capabilities and discoveries available to the broader research community. 


\subsection{Research Areas and Achievements}

\section{Research Areas}

The Biology and Biotechnology Research Program includes five divisions that reflect the research areas of interest within the Program. These Divisons reflect the scientific thrusts that comprise our strategic plan for bioscience at LLNL.

\section{Biodefense Division}

Our work in the biodefense field focuses on providing both the basic bioscience and the tools necessary to render bioterrorism ineffective. Currently our work focuses on

- advanced detection systems to provide early warning, identify populations at risk and contaminated areas, and facilitate prompt treatment, and

- DNA signature development and biological forensics technologies to identify the agent, its geographical origin, and/or the initial source of infection.

This division has a strong partnership with the Nonproliferation, Arms Control, and International (NAI) Security Directorate here at LLNL.

\section{Computational and Systems Biology Division}

The goal of the Computational and Systems Biology Division (CSBD) is to be a selffunded, nationally recognized, research program in computational and systems biology that is built upon LLNL strengths in computations and simulation science, with strong internal and external collaborations. The CSBD was formed in early 2002, and currently consists of four research groups with a total of about 20 staff. The division uses a wide range of chemical modeling methods, ranging from homology-based protein structure prediction to highly computationally intensive first principles molecular dynamics. In addition to the computer modeling groups, the CSBD includes an experimental protein science group that is working on several joint experiment/modeling projects. The CSBD's science is highly collaborative, with more than a dozen collaborations with BBRP and external research groups. The division is currently funded by a combination of NIH, DOE, and LLNL LDRD grants

\section{Genome Biology Division}

The goals of research in this division are to generate genomic resources for the biological research community and to translate information arising from the use and characterization of those resources into new clues regarding vertebrate evolution, gene regulation mechanisms, and gene function. Traditional genomics resources including the sequencing capability at the Joint Genome Institute and the I.M.A.G.E. Consortium cDNA collection continue to be valuable tools for use in this research area, as are new experimental and computational methods to link predicted genes and regulatory sequences to in vivo function. 


\section{Health Effects Genetics Division}

The long-standing focal areas for BBRP and the scientists of the HEG Division have been to understand the individual and population health consequences of radiation and chemical exposure. Both basic and applied approaches are used to identify and characterize the molecular, cellular and tissue mechanisms of response to exposures as well as the consequences of exposures in terms of disease risk. Components of these studies include translational studies linked to public health and risk assessment for reproductive defects as well as cancer. A common goal is the reduction of disease incidence and improvement in the standard of health for the population. HEG research has benefited from the broad expertise provided by multidisciplinary teams, the availability of biocomputing, and the implementation of enabling genomic and proteomic technologies.

\section{Molecular Biophysics Division}

The goals for this focus area are to develop and apply tools based on LLNL's capabilities in physical, chemical and engineering sciences to measure biochemical and cellular components and processes. Our emphasis is on generating data that supports predictive understanding of the biological world, including the use of complex simulations and modeling. Current tools such as accelerator mass spectroscopy, x-ray crystallography, nuclear magnetic resonance spectroscopy and high-throughput protein production technologies are applied to the following areas:

- pathway dynamics, including in vivo cellular diagnostics, intracellular transport, and cell-to-cell signaling,

- structural characterization, and

- protein function.

\section{Environmental Microbiology Group}

This is a new thrust area for BBRP which will bring "biology of scale" to microbial biology and apply this knowledge to the DOE missions in energy, security and environmental protection and restoration. We plan to grow this research area through mechanisms such as the DOE/OBER Genomes to Life Initiative.

\section{Bioinformatics Group}

The BBRP Bioinformatics Group presently consists of 20 programmers and programming technicians, plus system administration, computer security, and desktop support personnel. The group supports ongoing work within the BBRP program, plus CBNP and the Joint Genome Institute (JGI). Group members support a wide variety of projects, such as pathogen DNA and protein signature development, high-throughput DNA sequencing, microbial finishing, whole-genome analysis and annotation,

I.M.A.G.E. cDNA library analysis and maintenance, comparative genomics, mapping, and crystallography and protein structure efforts. The group is undergoing a period of rebuilding and restructuring to adapt to the new exigencies of Homeland Security, the completion of the human genome, and the emergence of new projects and thrust areas within BBRP, LLNL, and at the JGI. 


\section{Physical Biosciences Institute}

To help foster the application of physical science techniques in the life sciences, the LLNL University Relations Program has just created a new Physical Bioscience Institute (PBI). The emerging disciplines of "systems biology" or "quantitative biology" offer the promise of developing predictive models of biological process that could help interpret and design biological experiments. Fulfilling this promise will depend heavily on new technologies from the physical sciences and advanced computations. LLNL has many scientific and technical capabilities that could allow it to have roles in aspects of this "new biology" that are important to basic biosciences, as well as national security and other DOE missions. Moreover the scientific challenges in this field will be valuable in attracting and retaining the strong multidisciplinary talent.

The goal of the PBI is to attract and train future talent for LLNL life sciences by creating an incubator for multidisciplinary post-doctoral projects that link LLNL experimental and simulation capabilities to research projects in quantitative biology. To date the PBI has hired seven post-docs who will be participating on projects involving bioscience, physical science and engineering disciplines at LLNL and collaborations with the larger life sciences community.

Interaction between these research areas and related research programs that exist across the Laboratory help to weave a strong Bioscience Program at LLNL. 
(this page intentionally left blank) 


\section{Research Abstracts}

The following abstracts highlight research being reviewed from 2002 by our scientific advisory board. Titles and authors are listed below for abstracts found on the following pages.

Molecular characterization of the RAD51 paralog protein complexes Joanna S. Albala

DNA Repair: Genetic Variation and Individual Cancer Susceptibility Irene M. Jones and Harvey W. Mohrenweiser

Mechanistic studies on cellular responses to DNA damage using isogenic CHO knockout cells Larry H. Thompson and Robert S. Tebbs

Biological function of XRCC2 in homologous recombinational repair Nan Liu and Krzysztof Skowronek

Gene expression changes in mouse brain after exposure to low-dose ionizing radiation

Andy Wyrobek, Eric Yin, Matt Coleman, David Nelson

Novel multi-color FISH methods for detecting chromosomal structural aberrations in human and mouse sperm

Francesco Marchetti, Eddie Sloter, Francesca Hill and Andrew J. Wyrobek

High-throughput Structural Genomics of Human DNA Repair and Microbial Proteins

Matthew A. Coleman, Peter T. Beernink, and Brent W. Segelke

The Instrumented Cell

Allen Christian

Pathomics

K. Turteltaub, F. Milanovich, B.Colston, R. Langlois, S. McCutchen-Maloney, A. Quong 
Heterocyclic Amines PO1 update and UC Davis Cancer Center Collaborations

J. Felton

National Resource for Biomedical Accelerator Mass Spectrometry

Ken Turteltaub,and John Vogel

Designing Molecules to Fight Bioterrorism and Cancer

R. Balhorn, M. Cosman, F. Lightstone, J. Perkins

Livermore Protein Structure Prediction Center

Krzysztof Fidelis, Adam Zemla, Ceslovas Venclovas, Andriy Kryshtafovych

Protein Model Database Initiative

Alexei Adzhubei and Krzysztof Fidelis

Physical Biosciences Institute

Michael Colvin

LLNL Nuclear Magnetic Resonance Center for National Security

Monique Cosman 


\title{
Molecular characterization of the RAD51 paralog protein complexes
}

\author{
Joanna S. Albala
}

RAD51 forms nucleoprotein filaments on damaged DNA and catalyzes strand exchange in an ATP-dependent fashionThere are five paralogs of RAD51 in human cells, RAD51B, RAD51C, RAD51D, XRCC2, XRCC3, that form two distinct complexes in vivo, BCDX2 and RAD51C/XRCC3. Additional examination of the complexes by immunocytochemistry has confirmed the co-localization of RAD51B with XRCC2 but not XRCC3, further demonstrating the presence of BCDX2 in the cell. The function of the RAD51 paralogs in facilitating the DNA repair process remains to be elucidated. It has been postulated that these complexes participate in the processes of homologous recombination and DNA repair to maintain genome stability possibly by modulating the function of RAD51. Several experimental approaches are being pursued to elucidate the function of the RAD51 paralogs.

As RAD51C is a central player in both complexes, we are using molecular modeling to create deletion and point mutations for yeast two-hybrid analysis to determine the binding regions for these proteins on RAD51C to elucidate how the various paralogs may compete for binding to RAD51C. Our studies suggest that there are multiple binding sites for the RAD51 paralogs on the C-terminus of the RAD51C protein. In addition, we have shown that the N-terminus of RAD51B binds in this C-terminal region of RAD51C.

In order to identify additional protein partners for RAD51B and RAD51C, we have employed protein microarray techniques and have identified a novel protein interaction between the RAD51B and histone proteins. This interaction has been confirmed by Far Western analysis. We speculate that RAD51B may be involved in chromatin remodeling prior to repair of double-strand breaks by homologous recombinational repair. Future studies are aimed at understanding this interaction and defining the relationship of RAD51B in the process of chromatin remodeling.

As RAD51 has been shown to have ATPase activity, we have been interested in understanding the role of ATP in protein complex formation. We have initiated the construction of mammalian cell lines that over-express RAD51B and RAD51C wild type and ATPase mutant proteins. RAD51B and RAD51C mutant cell lines carry mutations in the conserved ATP-binding domain (Walker Box A) which lead to defective ATPbinding (K133A) or ATP-hydrolysis (K133R) capabilities in the RAD51 protein. These studies are key to understanding the roles of the RAD51B and RAD51C proteins as well as the significance of their intrinsic ATPase activities in the context of the whole cell. Combined, these studies are aimed at furthering our understanding of the BCDX2 complex in the processes of DNA repair. 


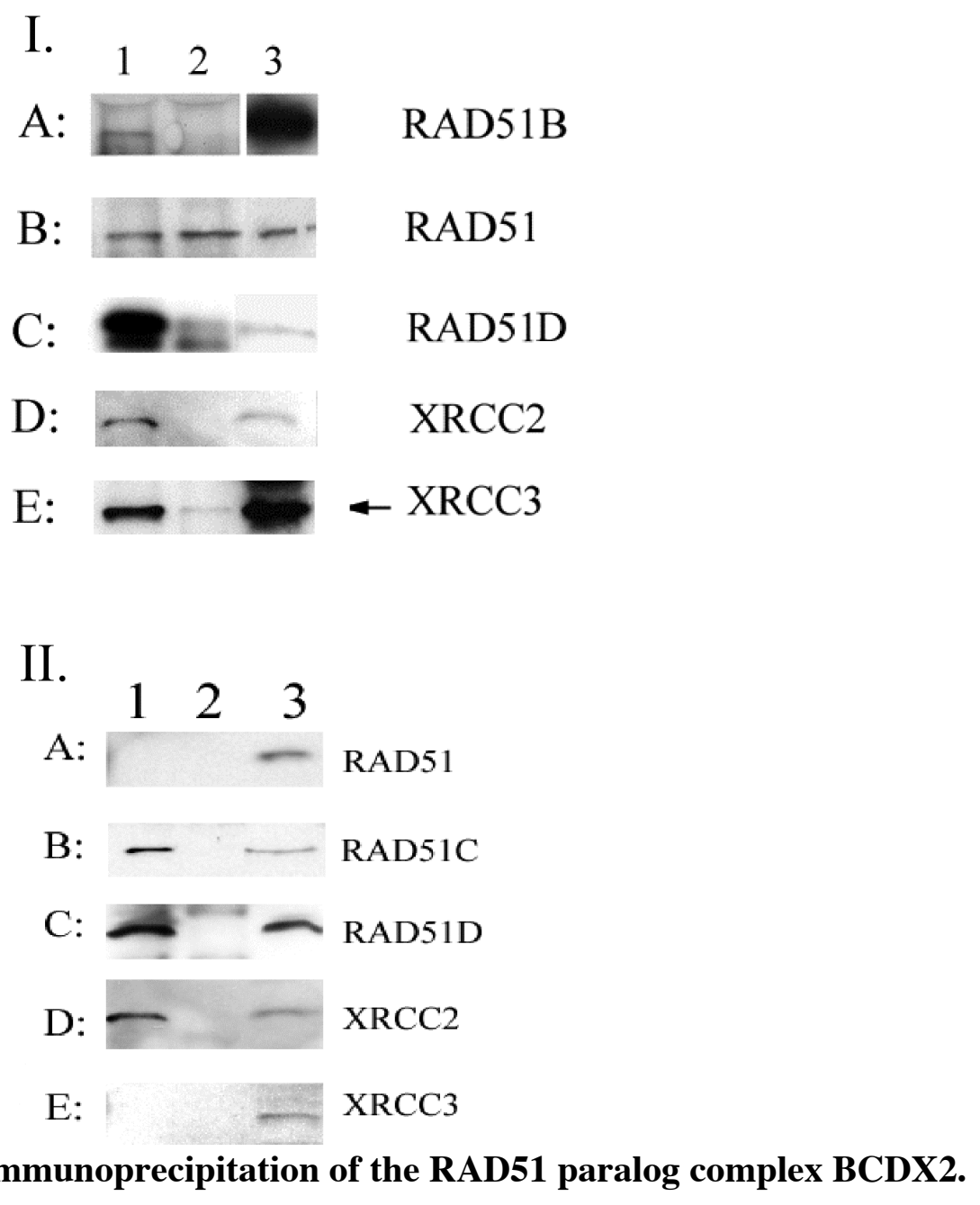

I. RAD51B, RAD51D, XRCC2 and XRCC3 form stable complexes with RAD51C. Lanes 1-3: HeLa whole cell extracts were immunoprecipitated with RAD51C antibody. Lane 1: Immunoprecipitation in $50 \mathrm{mM} \mathrm{NaCl}$. Lane 2: HeLa extracts immunoprecipitated with RAD51C antibody preadsorbed with RAD51C-specific peptide. Lane 3: Direct Western detection of endogenous protein $(100 \mu \mathrm{g})$. Each panel was individually incubated with antibody and visualized by ECL followed by autoradiography. Panel (A) RAD51 polyclonal antibody (1:2000), (B) RAD51B polyclonal antibody (1:500), (C) RAD51D polyclonal antibody (1:2000), (D) XRCC2 polyclonal antibody (1:500), and (E) XRCC3 polyclonal antibody $(1: 5000)$.

II. RAD51C, RAD51D, and XRCC2 form stable complexes with RAD51B. Lanes 1-3: HeLa whole cell extracts immunoprecipitated with RAD51B antibody. Lane 1: Immunoprecipitation in $50 \mathrm{mM} \mathrm{NaCl}$. Lane 2: HeLa extracts immunoprecipitated with RAD51B antibody preadsorbed with RAD51B-specific peptide. Lane 3: Direct Western detection of endogenous protein $(100 \mu \mathrm{g})$. Each panel was individually incubated with antibody and visualized by ECL followed by autoradiography. Panel (A) RAD51 rabbit polyclonal antibody (1:2000), (B) RAD51C monoclonal antibody (1:1000), (C) RAD51D polyclonal antibody (1:2000), (D) XRCC2 polyclonal antibody (1:500), and (E) XRCC3 polyclonal antibody $(1: 5000)$. 


\title{
DNA Repair: Genetic Variation and Individual Cancer Susceptibility
}

\author{
Irene M. Jones and Harvey W. Mohrenweiser
}

DNA damage and the potential loss of integrity of genetic information are a consequence of normal cellular processes, metabolism and replication, as well as exogenous environmental exposures. Repairing damaged DNA requires the action of a subset of $\sim 150$ proteins, functioning in damage specific, non-redundant repair pathways. Reduced ability to repair damaged DNA is a cancer risk factor. This is most apparent in familial cancer, where rare, loss-of-function variants have been identified as causative of the high risk. Individuals with less marked reductions in repair capacity, a genetic trait that integrates the activity of the genes in a pathway, are commonly observed in the population and these individuals are at moderately elevated cancer risk.

An average of over 5 amino acid substitution variants per gene have been identified in the systematic screening of $\sim 80$ DNA repair genes for sequence variants in a set of 90 healthy individuals from the DNA Polymorphism Discovery Resource (DPDR) that represent the ethnic diversity of the U.S. population. The polymorphisms existing at frequencies of $<10 \%$ comprise $90 \%$ of the variants and account for $\sim 35 \%$ of the total variation encoding amino acid substitutions at these loci. A typical individual will exhibit variation at one in every 3-4 loci. This translates into 9-12 variants (from a pool of $\sim 150$ different variants) in the genes of each repair pathway in the typical individual. Computational algorithms predict that $25 \%$ of the amino acid substitutions should dramatically impact protein function and another $25 \%$ of the substitutions will have a moderate impact on function. Half of the genetic variants that encode amino acid substitution polymorphisms are predicted to have a negative impact on the normal structure and activity of their proteins. These variants are expected to be the molecular and biochemical basis for the reduced repair capacity phenotypes associated with elevated sporadic cancer risk.

The challenge for molecular epidemiology is to utilize the large quantities of genotype data that can now be obtained. In our Program to develop approaches to relate genetic variation to risk we are focusing on the genes and function of the Base Excision Repair (BER) pathway. Using Random Forests Regression, which combines heuristic search techniques with regression, we have analyzed the relationship between genotype for 25 BER genes and two measures of BER capacity. Cell lines from 81 people from the DPDR were studied. BER genotype included 102 SNPs, 15 in upstream UTRs and 87 encoding amino acid substitution variants. Endogenous damage and amount of damage removed early after exposure to ionizing radiation, assessed by the alkaline comet assay, were the BER phenotypes studied. Seven SNPs were found to explain $29 \%$ of the inter-individual variation in endogenous damage. An overlapping set of 5 SNPs explained 18\% of interindividual variation in repair of radiation-induced damage. The polymorphic alleles predicted to impact protein structure and activity or associated with variation in repair capacity should be priority candidates for additional analysis of activity and study of individual genetic susceptibility to exposure and variation in the risk of sporadic cancer in the general population.

Continued development of new analytical strategies will enable us to take full advantage of the extensive genetic variation in genes associated with differences in risk of many exposure related diseases. Knowledge of individual susceptibility is one component of strategies to reduce the health consequences of exposures to environmental agents, such as radiation, chemicals and biologics, including infectious agents. 


\section{"The environment"}

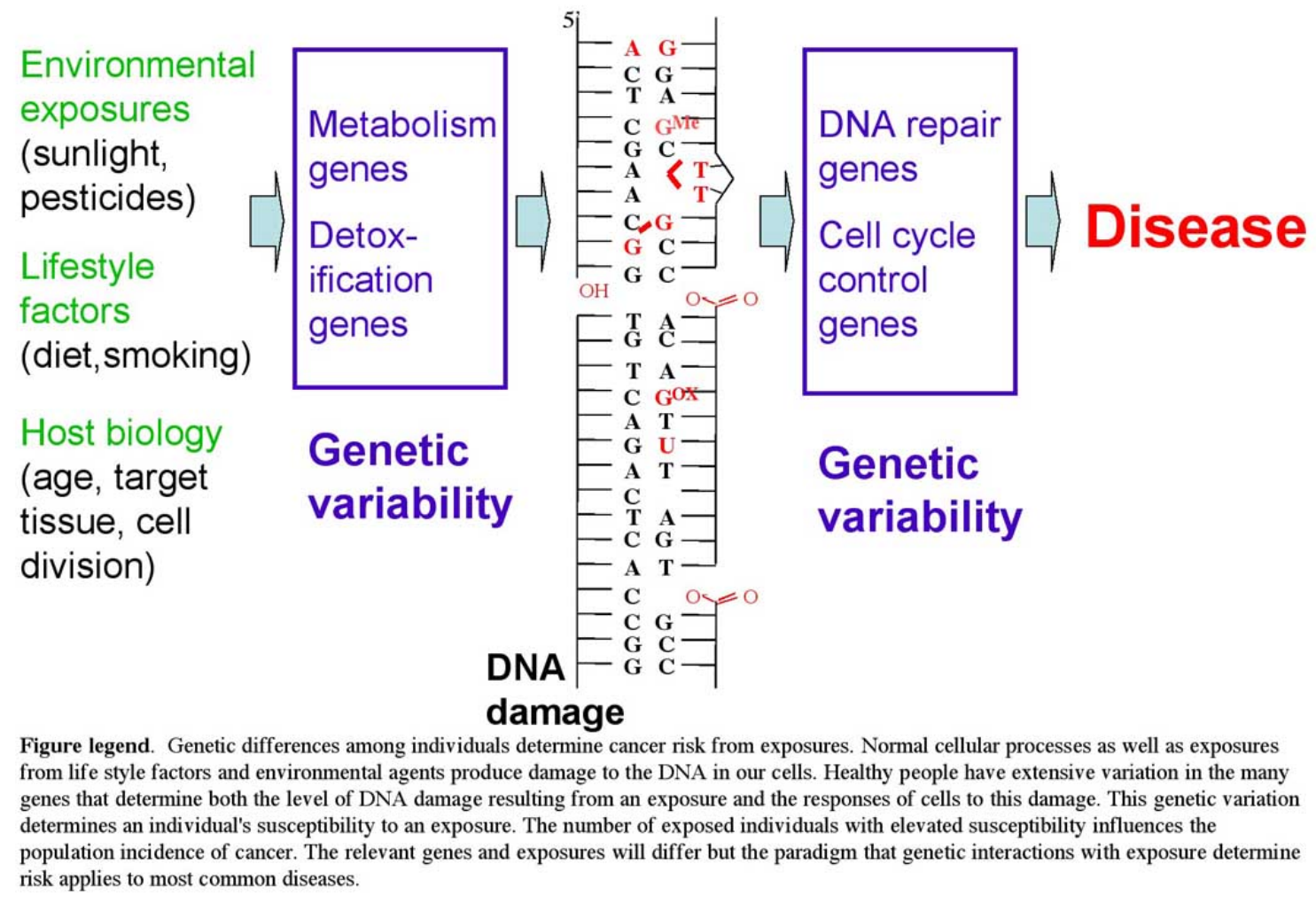




\section{Mechanistic studies on cellular responses to DNA damage using isogenic CHO knockout cells \\ Larry H. Thompson and Robert S. Tebbs}

DNA repair is essential for life to maintain genetic integrity. Over one hundred DNA repair genes have been identified, some of which are responsible for human genetic disease (e.g. xeroderma pigmentosum, and Cockayne's syndrome). DNA repair is just one component involved in the cells response to DNA damage. It is becoming increasingly clear that cells coordinate a response to DNA damage through a network of proteins that include damage recognition and signal transmission to effector proteins that attenuate the cell cycle, initiates repair or induces apoptosis; and the challenge for the future is to determine the molecular details of this elaborate and intricate network.

We create CHO-based cell systems to study mechanisms of DNA repair and damage response. We recently created CHO knockout cells deficient for the Fanconi anemia group G gene (FANCG), which we labeled FGKO40. Fanconi anemia is an autosomal recessive cancer susceptibility disorder characterized by progressive bone marrow failure and congenital abnormalities. Eight complementation groups were identified and 7 genes have been cloned. Historically Fanconi anemia was classified a DNA repair disorder, based on cellular phenotypes of chromosomal instability and DNA cross-link hypersensitivity, but new evidence does not fully substantiate that claim and the function of the FA pathway is presently unclear. FGKO40 cells, together with the parental and gene-corrected controls, provide an isogenic system that allows for the identification and accurate measurements of the cellular defects associated with FANCG deficiency. Thus, FGKO40 cells were systematically characterized for mutagen sensitivity, cell cycle defects, chromosomal instability, mutation rate frequencies, and deficiencies in oxygen metabolism. FGKO40 cells exhibit increased sensitivity to diverse mutagens, including DNA cross-linking agents, methylating compounds and inhibitors of DNA synthesis. FGKO40 cells exhibit a 1.6-fold elevation in ROS using an oxygen-sensitive fluorophore, but little or no increase in spontaneous chromosomal aberrations. FGKO40 cells have a slightly lengthened G2 phase, and after MMS treatment they have more G2 delay than control cells. FGKO40 cells exhibit a slight reduction in hprt mutation rates, measured by fluctuatioin analysis, but an increase in gene amplification of the dhfr locus determined by methyltrexate resistance.

FGKO40 cells are being used to create and test molecular models responsible for Fanconi anemia. First, we examined FGKO40 cells for deficiency in repair of methylation damage, since FGKO40 cells are 4-fold hypersensitive to methylating agents. FGKO40 cells exhibit normal levels of spontaneous and methylation-induced DNA damage, and a normal rate of repair of MNU-induced damage indicating DNA repair of methylation damage is normal. We also examined the hypothesis that elevated oxygen tension is exacerbating the hypesensitivity to DNA crosslinking or methylating agents. FGKO40 cells showed no correction of MMC hypersensitivity in hypoxic conditions, nor correction for MMS hypersensitivity by the addition of the antioxidant N-acetylcysteine to the media suggesting elevated ROS is not responsible for FGKO40 mutagen hypersensitivities. Overall, the phenotypes of FGKO40 cells suggest a defect in DNA damage response upstream of DNA repair, possibly associated with blocked replication forks. Indeed, we do show elevated RAD51 foci following MMC and MMS treatment which might reflect an increase in blocked or collapsed DNA replication forks at sites of damage. 
(this page intentionally left blank 


\title{
Biological function of $\mathrm{XRCC} 2$ in homologous recombinational repair
}

\author{
Nan Liu and Krzysztof Skowronek
}

Human and mouse XRCC2 genes were isolated in our lab by functional complementation in hamster mutant irs 1 cells, which are hypersensitive to various DNA damaging agents and exhibit chromosomal instability. Analysis of the protein sequence revealed that XRCC2 is structurally related to Rad51, a RecA homolog that plays a central role in homologous recombinational repair (HRR) of DNA double strand breaks (DSB). Using a recombination reporter system, it was demonstrated by Johnson et al that XRCC2 plays an essential role in repair of the restriction enzyme-induced DSB mediated by homologous recombination. To understand the function of XRCC2 in HRR, we studied the interaction of XRCC2 with other Rad51 paralogs (XRCC3, Rad51B, Rad51C and $\operatorname{Rad51D})$, the functional association of XRCC2 with Rad51 and Rad52, and the biochemical activity of XRCC2. We identified that Rad51 paralogs interact to form two distinct complexes in mammalian cell extracts, one contains XRCC2, Rad51B, Rad51C and Rad51D (BCD2), and the other contains Rad51C and XRCC3 (3). Rad51C is involved in both complexes. Our results also showed that XRCC3-Rad51C complex interacts with Rad51 in vivo. Although a physical interaction of BCD2 complex with Rad51 was not observed, we found that irs 1 cells are defective in formation of Rad51 foci after ionizing irradiation or DNA cross-linking agent mitomycin $\mathrm{C}$ treatment, and the defect can be corrected by expression of XRCC2 in the mutant. These results suggested that XRCC2 is functionally associated with Rad51 and is required for the assembly of DNA damage-induced Rad51 foci, which may present the Rad51 nuclearprotein filaments on the HRR sites. A number of proteins, such as replication protein A (RPA), Rad52 and Rad51 paralogs, are suggested to modulate or facilitate the process of Rad51 filament formation. Interestingly, we found that overexpression of Rad52 conferred partial survival resistance to ionizing radiation in irs1 cells. In addition, the irs 1 cells overexpressing Rad52 showed decreased frequency of chromatid aberrations and increased capability of Rad51 focus formation induced by ionizing radiation. These results suggest that XRCC2 may act as a mediator to Rad51, and the function of XRCC2 may overlap with that of Rad52 in the early stage of HRR. To determine the biochemical activity of XRCC2, we overexpressed human XRCC2 and Rad51D, the direct interacting partner of XRCC2, in E. coli. Both XRCC2 and Rad51D proteins have been purified to $80 \%$ and $90 \%$ purity, respectively, with the relatively high yields of $1-2 \mathrm{mg} /$ litter of culture for XRCC2 and 2-3 mg/litter of culture for Rad51D. Several truncated forms of human XRCC2 and Rad51D have also been expressed in E.coli and purified. The purified XRCC2 and Rad51D proteins will be used to characterize their biochemical activities, such as ATPaes, DNA binding, strand pairing and exchange, and the modulate activity on Rad51. Rad51C and Rad51B proteins will be obtained through collaboration and the activity of BCD2 complex will be examined. The purified proteins will also be used in protein structure analysis. We also investigated the protein interaction between XRCC2 and Rad51D using truncated protein fragments expressed in E. coli. Our preliminary results showed that the RecA-like core regions in both XRCC2 and Rad51D are essential for the interaction between the two proteins. Multiple domains for the interaction may present in the RecA-like core region of XRCC2. Taken together, our results suggest that XRCC2 play an important role in Rad51-mediated homologous recombination to ensure the maintenance of genetic integrity and stability. 
A.
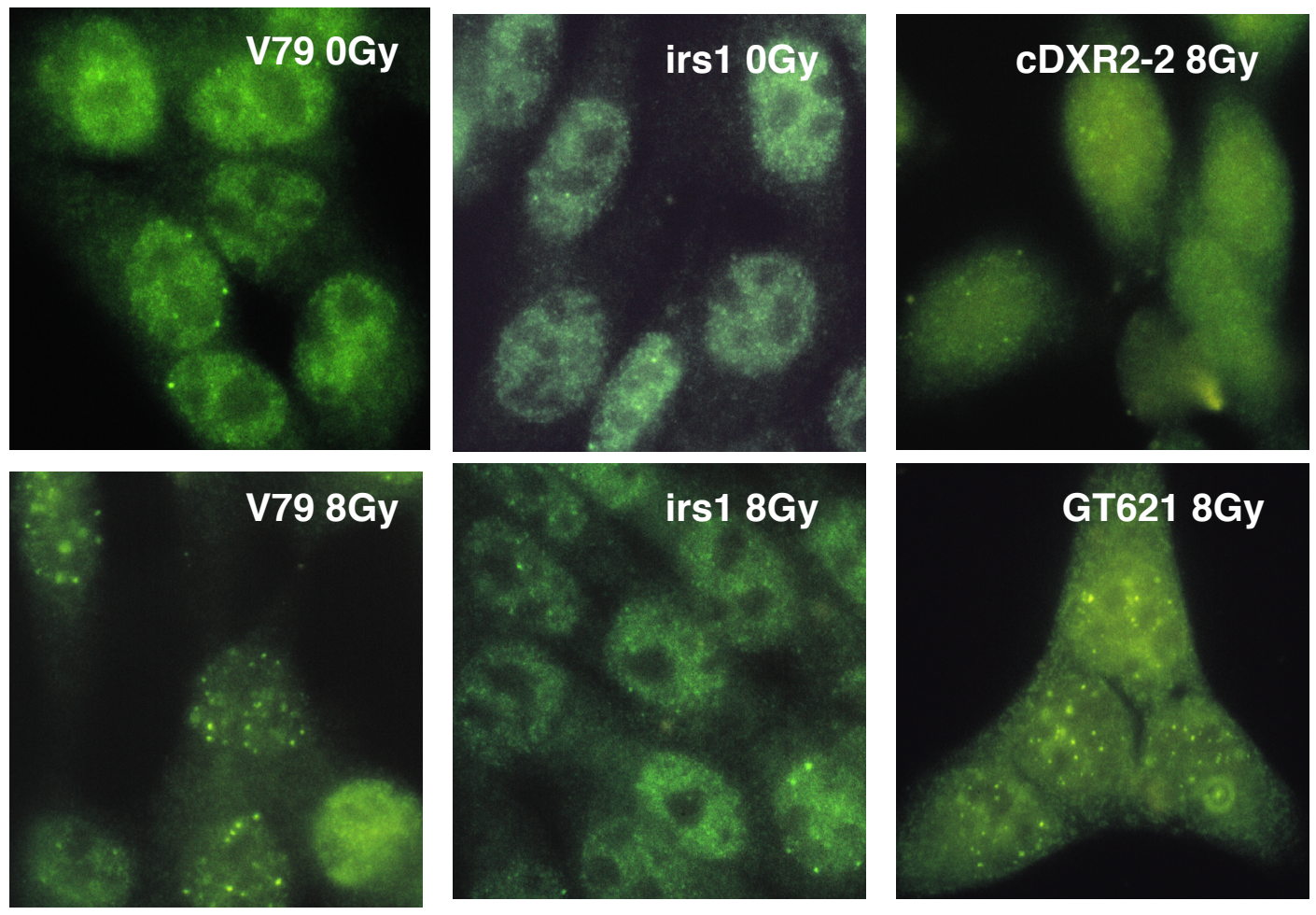

B.
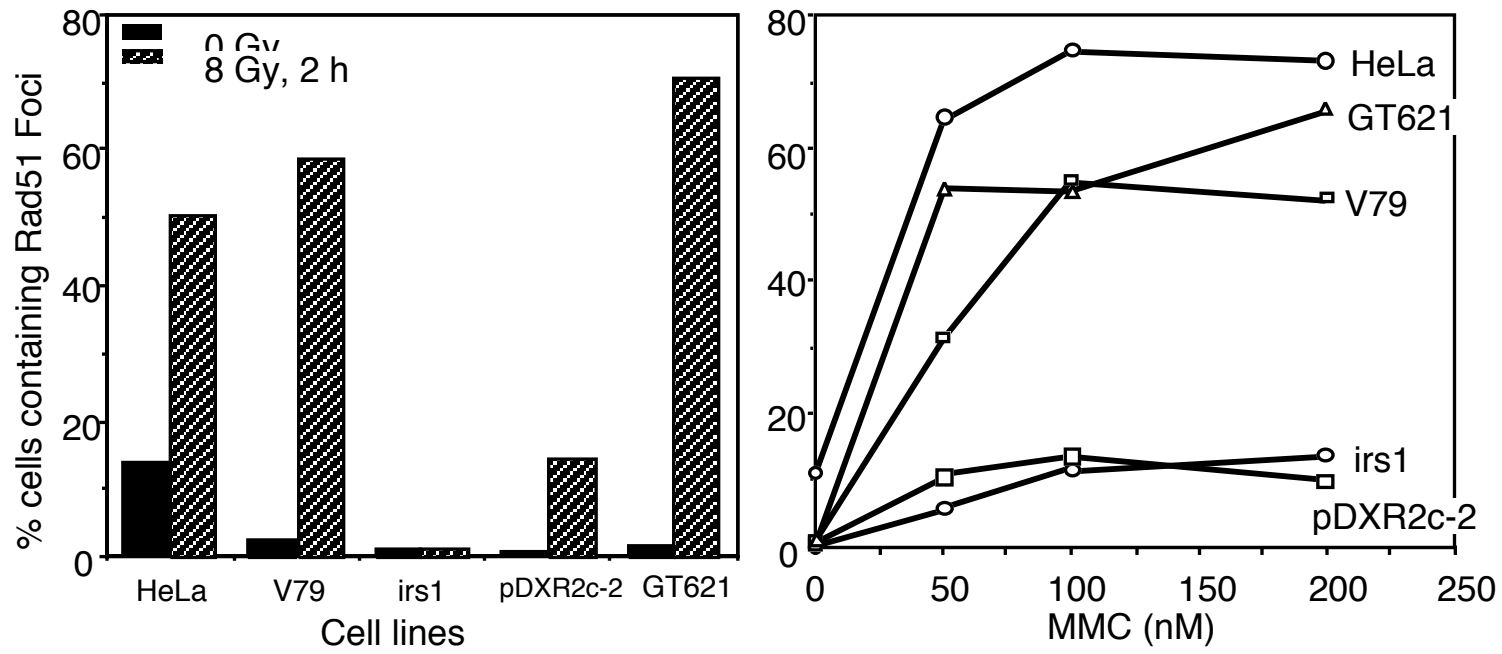

Figure legend: (A) Ionizing radiation-induced Rad51 focus formation at $2 \mathrm{~h}$ in wild-type (V79), $x r c c 2$ mutant (irs1), XRCC2 cDNA transformant (cDXR2-2) and XRCC2 genomic DNA transformant (GT621). Cells were fixed and stained with rabbit anti-mouse Rad51 antibody. (B) Percentage of cells containing Rad51 foci after 8 Gy g-ray irradiation (left panel) and MMC treatment (right panel). 


\title{
Gene expression changes in mouse brain after exposure to low-dose ionizing radiation
}

\author{
Andy Wyrobek, Eric Yin, Matt Coleman, David Nelson
}

As part of the DOE Low dose program, we conducted a genome-scale survey of the effects of low dose ionizing radiation on gene expression changes in the brain of irradiated mice. RNA from the cerebrum of $\mathrm{B} 6 \mathrm{C} 3 \mathrm{~F} 1$ mice was evaluated on oligonucleotide expression microarrays at 30 minutes and 4 hours after whole-body irradiation with either 0.1 Gy or 2 Gy of gamma radiation. Transcript levels for 855 of 9977 genes were modulated $\geq 1.5$-fold after IR exposure. Affected genes were assigned to four major expression groups based on time- and dose-response patterns. Roughly $30 \%$ of modulated genes showed dose-dependent expression patterns, including those exclusively modulated after $0.1 \mathrm{~Gy}$ or $2 \mathrm{~Gy}$ exposures. The remainder exhibited similar responses at both doses. About $60 \%$ of genes showed time-dependent responses, with more changes in transcript levels occurring at 30 minutes than 4 hours. Low-dose exposure resulted in early changes in genes involved in signal transduction, ion regulation and synaptic signaling. Late changes involved a number of metabolic pathways including myelin and protein synthesis. There were also changes in expression of genes involved in stress response, cell-cycle control, and DNA synthesis/repair. This study suggests that doses of $0.1 \mathrm{~Gy}$ induced changes in gene expression that were qualitatively different from those seen at a higher dose. The brain appears to respond to low dose irradiation by evoking protective as well as reparative mechanism while downregulating genes involved in neural signaling.
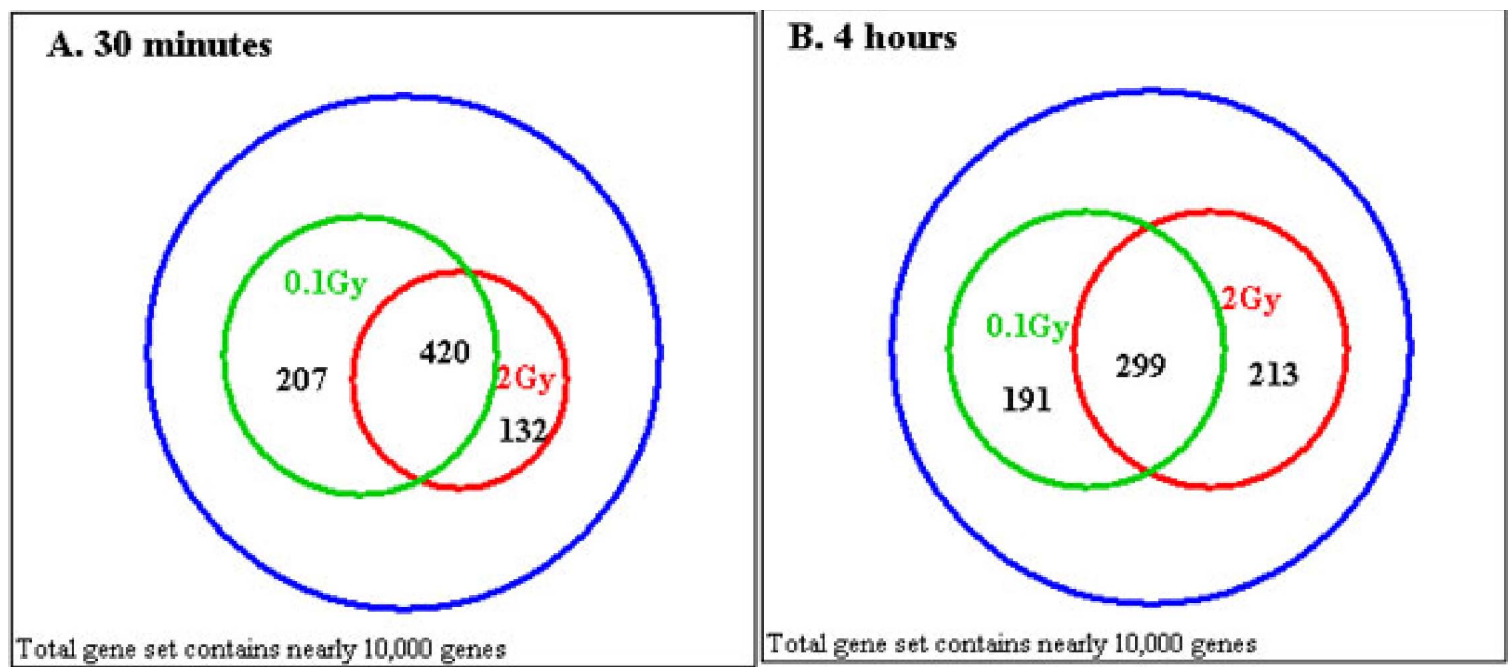

Figure 1. Variations in the time-dependent patterns of expression patterns after ionizing radiation. The distribution of genes across different time patterns suggested a temporal linkage between early and later cellular response for genes associated with various functions. For example, genes which are modulated at 30 minutes may show transitory changes (patterns $2 \mathrm{~A}, 2 \mathrm{~B}$ ), or sustained changes (patterns 1A, 1B). Genes which were transitorily modulated at 30 minutes, are followed by a different set of genes at 4 hours after IR exposure. 


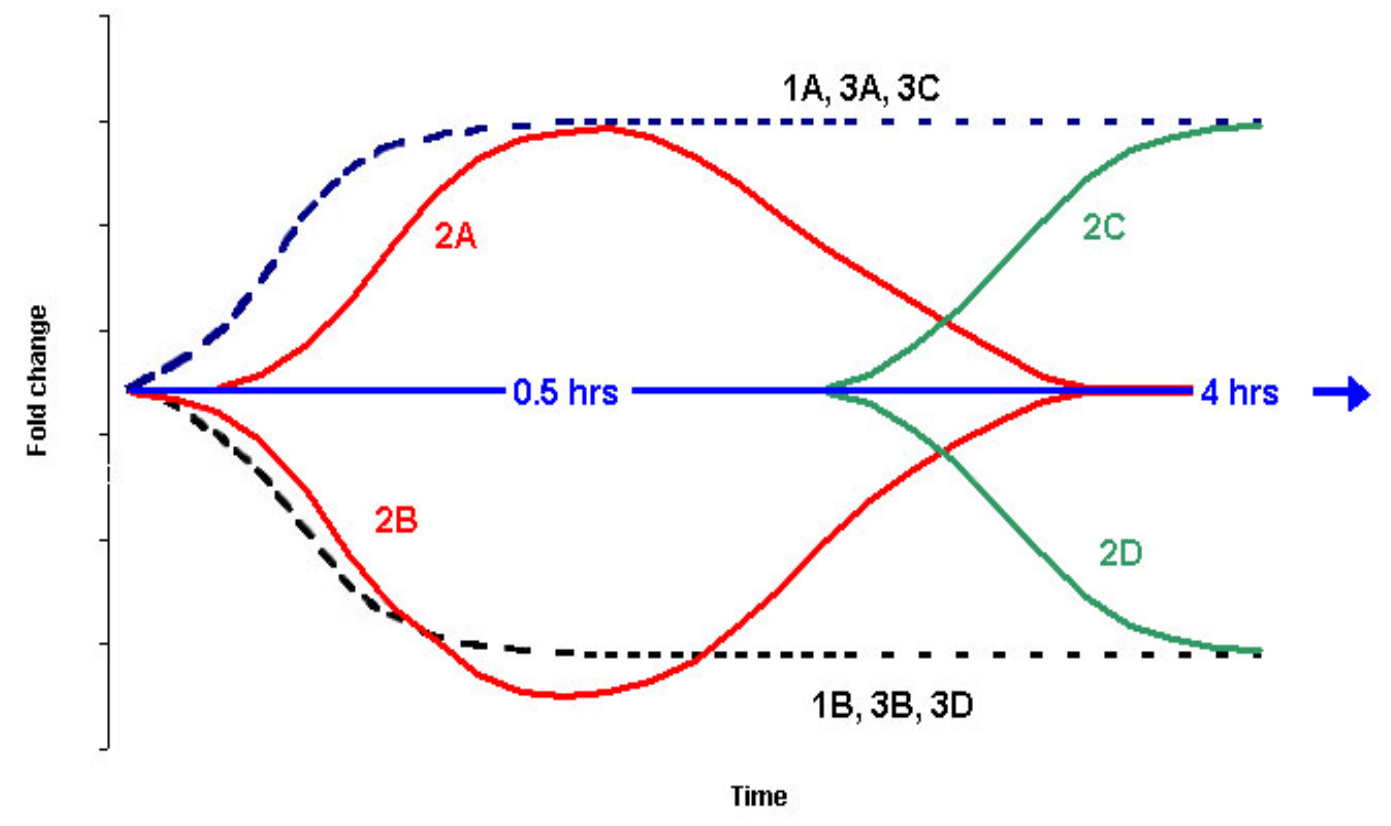

Figure 2. Venn diagrams of the relative numbers of genes showing dose effects on gene expression at two post-exposure time points.

Of the 1574 affected genes, 759 genes were modulated at 30 minutes, while 703 were modulated at 4 hours by $\geq 1.5$-fold. As shown in this figure, at both time points there were exclusive sets of genes where modulation exceeded the fold change criteria for one dose, but not the other, suggesting qualitative differences in the responses at the two doses. As shown in Panel A, more genes were modulated at 0.1 Gy than at 2 Gy at the 30 minute time point, while the number of genes that showed altered expression at 4 hours were more evenly distributed (Panel B). 


\section{Novel multi-color FISH methods for detecting chromosomal structural aberrations in human and mouse sperm \\ Francesco Marchetti, Eddie Sloter, Francesca Hill and Andrew J. Wyrobek}

De novo aberrations in chromosome structure represent important categories of paternally transmitted genetic damage that are associated with a variety of abnormal reproductive outcomes including pregnancy loss, infant mortality and genetic diseases including cancer. We have developed fluorescence in situ hybridization (FISH) methods to detect chromosomal structural aberrations in sperm of men and mice. The human method, called ACM, uses three probes specific for three regions on chromosome 1 (Figure 1) to detect three classes of chromosomal defects: (1) partial duplications and duplications of chromosome 1, (2) chromosomal breaks near the centromeric region, and (3) numerical abnormalities of chromosome 1 . We have used this method to show that the frequencies of sperm with chromosome structural aberrations increased as a function of age (Figure 2 ). The rate of increase was about $\sim 3 \%$ for every year of age. Conversely, numerical abnormalities were unaffected. The corollary mouse method, called CT8, uses centromeric and telomeric probes for chromosome 2 and a probe for chromosome 8 for the simultaneous detection of three types of chromosomal damage in mouse sperm: (1) duplications and deletions involving chromosome 2; (2) aneuploidies involving chromosome 2 and 8; and (3) sperm diploidy (Figure 3). The baseline frequencies of sperm with structural aberrations in mice are more than 5-fold lower than the spontaneous frequencies of human sperm with chromosome structural aberrations. As FISH assays continue to be developed and applied in various species it will become increasingly possible to perform comparative studies of animal-to-animal variations within species, variation among species, and the relative differences among species in response to environmental exposures (chemical, physical and microbial agents) or physiological factors (e.g., age, diet). Thus, FISH-based procedures for simultaneously detecting chromosomal breaks, rearrangements, and numerical abnormalities in sperm have promising widespread applications in genetics, genetic toxicology, and reproductive medicine in a broad variety of species. 

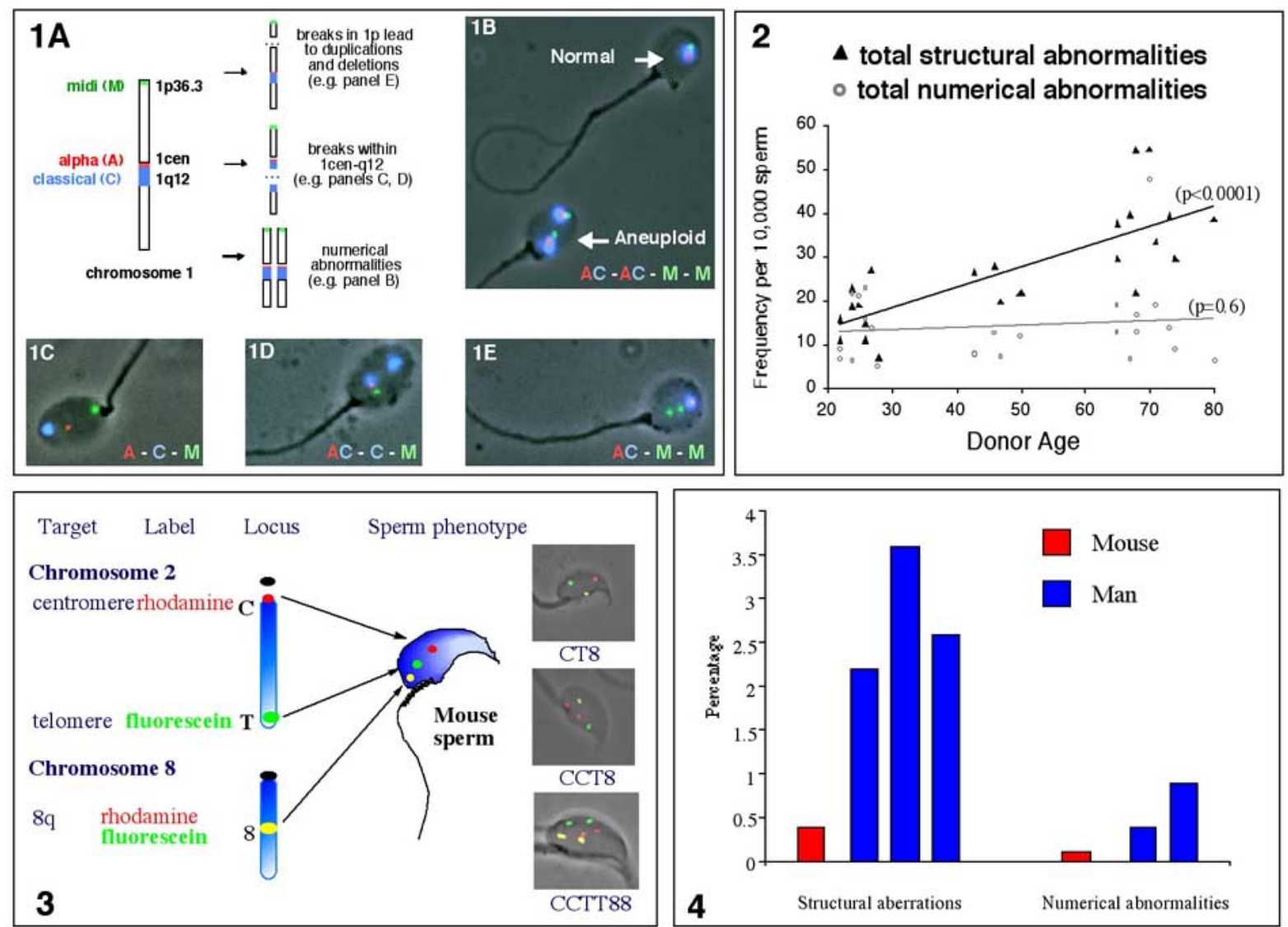

Figure 1: Panel A: Scheme of the Human ACM assay showing the probe location, labeling scheme, and the three types of abnormalities that can be detected. Panels B-E: Photomicrographs of abnormal sperm detected by ACM FISH. Panel B, Sperm containing two copies of chromosome 1 (bottom) indicating either disomy 1 or sperm diploidy. Panel C: Example of a sperm with a chromosome break directly between 1cen and 1q12. Panel D: Example of a sperm with a chromosome break within 1q12. Panel E: Sperm with a terminal duplication of 1p36.3. Sperm were imaged at 1000x under fluorescence and phase-contrast. Figure 2: Frequencies of sperm with structural aberrations (black triangles) and numerical abnormalities (white circles) in men of various ages. Figure 3: Scheme of the mouse CT8 assay showing the probe location, labeling scheme and a sperm with the normal FISH phenotype. Photomicrographs are showing: a normal sperm (CT8); a sperm with a duplication of the centromeric region of chromosome 2 (CC $\mathrm{T} \mathrm{8)}$; and, a diploid sperm (CC TT 88). Figure 4: Comparisons of the frequencies of sperm with structural aberrations and numerical abnormalities in mice and men. The results from the CT8 assay were compared with similar assays in humans (each bar represents a different study). 


\section{High-throughput Structural Genomics of Human DNA Repair and Microbial Proteins}

Matthew A. Coleman, Peter T. Beernink, and Brent W. Segelke

With the quantity of sequence data provided by the Human Genome Project and other sequencing efforts, a significant challenge is presented to the research community, which is to understand and make use of this information. The genome project has revealed how little we really know of biology, as most of the genes discovered have no known function or homology to known genes. The new frontier in biological research is to characterize the proteins encoded by these genes through informatics or large-scale experimental initiatives, called proteomics. There are a number of pilot proteomics projects underway using high-throughput structure determination, or structural genomics, but they have all run into significant bottlenecks that need to be overcome along with a need for increased throughput and reduced cost. The biggest bottlenecks for such studies are protein expression, purification, and crystallization as the majority of proteins do not express well and intrinsically have only moderate solubility, making them inadequate for structural studies. The approach we have taken is the development of rapid in vitro protein expression testing and functional analysis, which enables us to select targets from a collection of many proteins. Our methodologies have allowed us to screen $\sim 350$ individual proteins for various aspects of protein yield, solubility, and function on a protein microarray. We have also developed in-house protocols for protein engineering to modify the inherent solubility of identified protein targets to help pull many more proteins through to our highly efficient automated crystallization screening protocol (CrysTools). In collaboration the crystallization center has been able to produce protein crystals from $33 \%$ of the proteins processed.

\section{Modular Proteomics Technologies}

1. Informatics for

Targeting

2. Shuttle Vectors for Cloning

3. High-throughput Expression Screening

4. Semi-automated Protein Purification

5. Protein Interaction Microarrays

6. Automated Crystallization
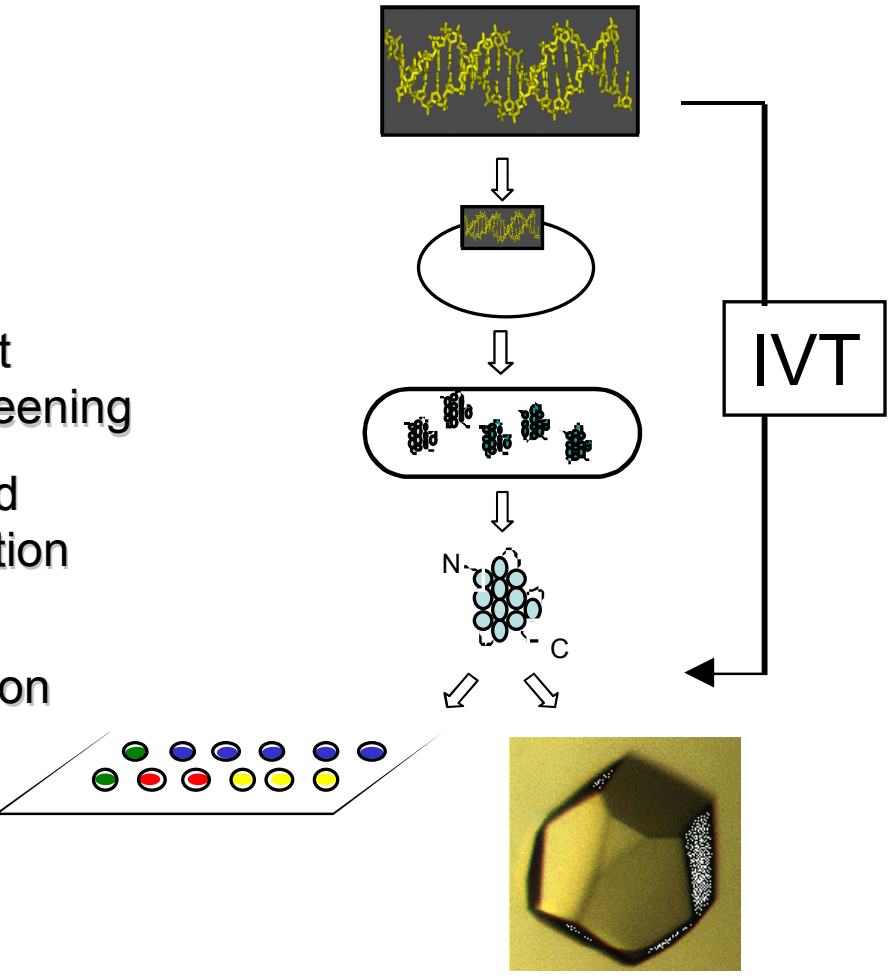


\section{The Instrumented Cell}

\section{Allen Christian}

There is a growing interest in the prospects for a new "quantitative biology", in which experimental data is integrated into predictive models of biological that can in turn be used to design and evaluate new experiments. There are many challenges to realizing this vision of quantitative biology; perhaps the most significant being the need to get precise data on the concentration and distribution of cellular components that will be required to develop such models. We believe there are many analytical capabilities at LLNL that show promise for enabling quantitative measurements of cellular processes in individual cells. The goal of the proposed Instrumented Cell project is to develop and apply technical capabilities to measure and manipulate biochemical concentrations at the single-cell level with the ultimate goal of developing quantitative models of cellular processes. We are collaborating with the LLNL Microfabrication Facility to develop microstructures to isolate cells and make single cell measurements with the analytical tools possessed by the Chemistry and Energy and Environment directorates. Our nearterm goal is to produce tools capable of manipulating the environment of individual cells, and producing analytical measurements of the cells' reaction to stimuli. These capabilities will provide quantitative data on an individual cell's responses to stimuli, and will be a platform for researchers internal and external to LLNL for precise biological measurements. To demonstrate the capabilities of the device, we will measure various biological properties in which the data collected from single-cell measurements may differ significantly from those collected from large, heterozygous cell populations. These processes include DNA synthesis, glycolysis and viral infection, measured first in a large population of cells and then in individual cells.

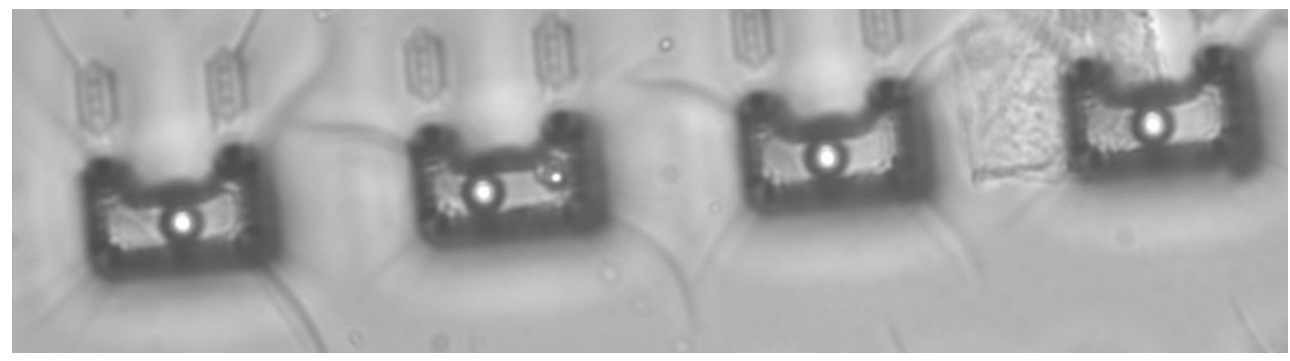

Human cancer cells captured in a LLNL-developed cell holder. 


\section{Pathomics}

K. Turteltaub, F. Milanovich, B.Colston, R. Langlois, S. McCutchen-Maloney, A. Quong

"Pathomics" is a comprehensive strategy to develop a systems level understanding of an individual's response to infectious disease agents, particularly those that represent a threat from bioterrorism. Its overall goal is to predict all possible routes of pathogenicity and host response from our understanding of the genes and mechanisms involved and to have detection systems that will determine that an attack or disease outbreak is beginning prior to people becoming overtly sick. Over the tenure of this project, we will demonstrate that detection of disease is possible presymptomatically and explore whether molecular signatures exist that can distinguish between pathogen types. We will propose a preliminary type of diagnostic platform and demonstrate its use in public health surveillance. Finally we will utilize the laboratories extensive capabilities in informatics and computational modeling to create preliminary models of combined pathogen and host response systems or pathways and show that they can be used to distill common pathogenic mechanisms. This program will integrate many LLNL capabilities (computations, chemistry, physics and applied technologies, biological sciences, and mission in homeland security through the nonproliferation, arms control and international academic community to develop the basic science and diagnostics needed. 


\section{Heterocyclic Amines PO1 update and UC Davis Cancer Center Collaborations \\ J. Felton}

The Heterocyclic Amines program project began work in May 2002 and will be funded for five years at approximately $\$ 2.6$ million per year (total dollars). Official start date was February. Some of the Projects had a slow start because of staff on loan to other efforts during the funding hiatus. Because of this and the February start, some carry-over money will be left in the budget in February 2003. The spending rate of the Projects and Cores has been adjusted so that this carry-over will be spent out over the next 4 years. Especially critical is Project 5 that was cut so dramatically by the $20 \%$ increase rule; it is hoped that much of the carry-over can be used to make this project stronger scientifically. This includes collecting some samples for analysis in Core A. Presently, no biological samples are being collected from the African American Prostate Population in this Project 5 study.

Scientifically things are going extremely well. The use of some very exciting new technologies at LLNL is driving the science quite quickly. This includes SIMS-TOF for visualizing $\mathrm{PhIP}$ in single cells, a specialized siRNA technique for interrogating pathways, much more comprehensive microarray analysis, good structures for P450 based on homology modeling, and new CHO cell lines with enhanced UGT expression.

The Program Project has brought dividends in spin-off research in digestion and uptake of heterocyclic amines, chemoprevention, and natural product therapy. New grants have been submitted, including an NCI grant with a 135 priority score from Kris Kulp, one of our young investigators. She will be investigating cell proliferation with PhIP and herbal teas taken by women trying to prevent recurring breast cancer. Both these compounds do the wrong thing; they stimulate the estrogen receptor. Additional grants have been awarded to Ken Turteltaub and Karen Dingley in areas that also complement the PO1 nicely.

Our alliance with the UC Davis Cancer Center in many of their Programs has been enhanced by this PO1 and many of these new grants are collaborations between the two institutions. These collaborations stem from our fundamental research on heterocyclic amines and the use of unique facilities and resources at LLNL. UC Davis provides the clinical expertise not available at LLNL. LLNL scientists are also involved in cancer therapy projects and basic oncology efforts at UC Davis. Especially noteworthy is the radiotherapy PO1 grant by the DeNardo's at Davis which includes Mike Colvin (modeling), Rod Balhorn (synthetic antibodies), Felice Lightstone (modeling), and Christine Hartmann-Sinatar (dosimetry). This grant has just been reviewed for the $2^{\text {nd }}$ time by an NCI study section with very positive comments. 


\section{National Resource for Biomedical Accelerator Mass Spectrometry \\ Ken Turteltaub and John Vogel}

Accelerator Mass Spectrometry (AMS) is a mass spectrometric method for quantifying extremely low concentrations of long-lived radioisotopes, such as the commonly used biochemical tracer 14C. AMS can measure attomoles of radiocarbon with a precision of better than $10 \%$. This corresponds to the need for less than 0.1DPM-equivalent of labeled agent per gram of biological sample. AMS has use when sample is limiting, specific activity is very low, when the level of isotope that can be used is very limited (humans studies) and when trying to study events that occur with very low frequency or at very low concentration.

The National Resource for Biomedical Accelerator Mass Spectrometry has been established to make AMS available to biomedical researchers who have a need for accurately measuring very low levels of $14 \mathrm{C}$ in their research. The Resource is also working to develop AMS into a routine tool for analysis of radioisotopes in biomedical tracer studies through development of new methods and instrumentation.

The Resource for Biomedical AMS is a U.S. National Facility, established and funded by the National Center for Research Resources (NCRR) at the National Institutes of Health (NIH). It is located within the Center for Accelerator Mass Spectrometry (CAMS) and the Biology and Biotechnology Research Program (BBRP) at LLNL. Although investigators do not need to have NIH funding to utilize the Resource, priority is given to research projects that are NIH funded.

The Resource has three major functions:

1. To provide biological researchers with access to 14C AMS in their research.

The Resource can be utilized by biomedical researchers either for single experimental projects or for program projects that describe a series of intellectually linked experiments. 2. To develop new methods and instrumentation for the use of AMS in biomedical research.

The routine use of AMS in biomedical research requires development of robust instrumentation and methods capable of either processing or analyzing a large number of samples of varying composition and having large variations in isotope concentration. 3. To demonstrate new applications and to educate the biomedical research community on AMS.

Training in the use of AMS is critical to ensuring successful use by biological researchers. We provide facilities and expertise to train and work with investigators, postdoctoral scientists and students using AMS in their research.

More information about the policies and procedures for utilizing the Resource may be found at the website: http://www.llnl.gov/bioams/.

The following personnel also contributed to this work: G. Bench, K. Burkhart-Schultz, K. Dingley, K. Haack, P. Henderson, T. Ognibene, E. Ubick 


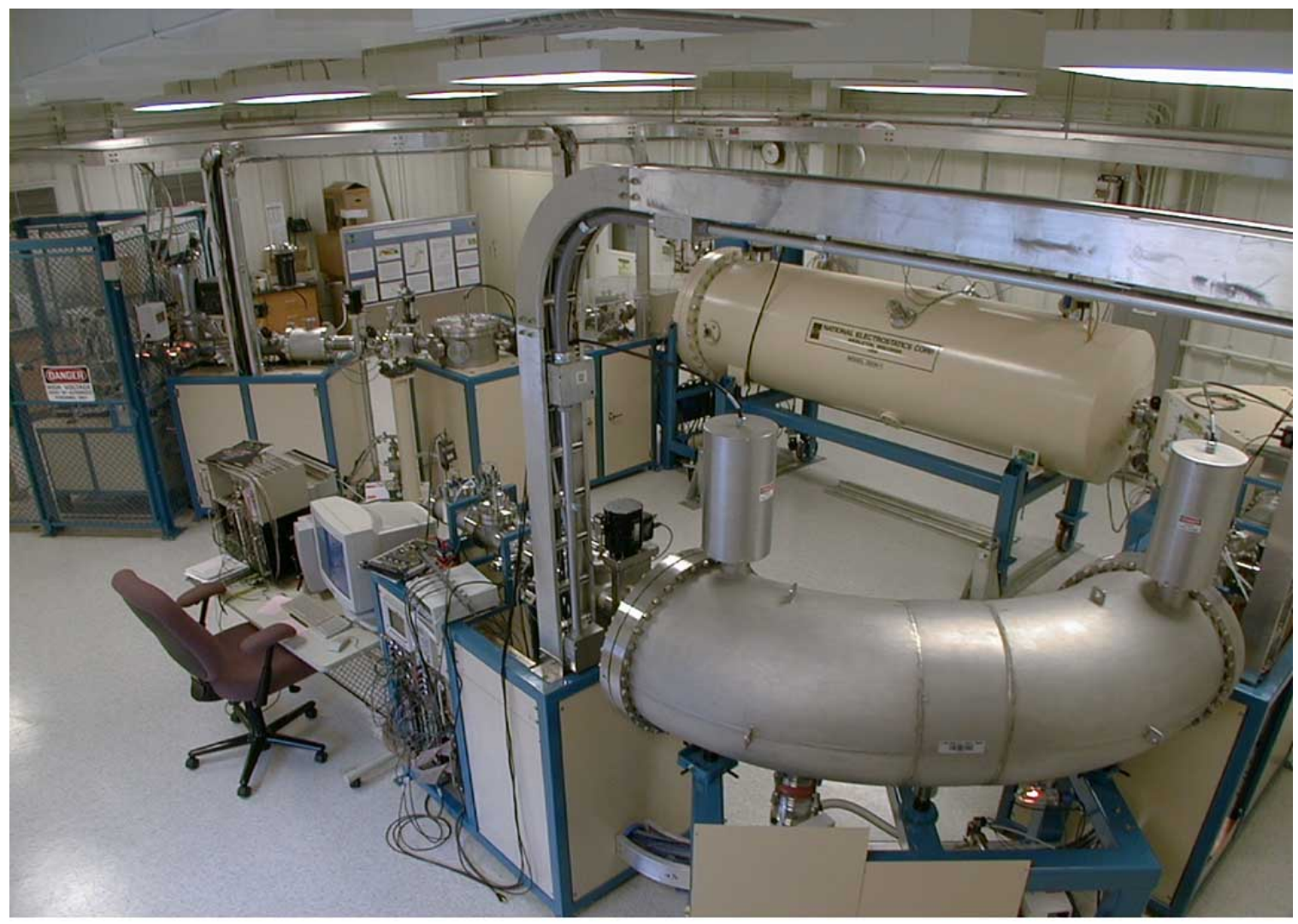

Figure legend: 1 MV Accelerator Mass Spectrometer used for the analysis of biomedical samples 


\title{
Designing Molecules to Fight Bioterrorism and Cancer
}

\author{
R. Balhorn, M. Cosman, F. Lightstone, J. Perkins
}

Recently, new methods have been developed that enable the design and synthesis of relatively small molecules that bind to the surfaces of proteins and other molecules with both high affinity and specificity. The approach mimics the method commonly used by biological molecules, such as antibodies, to establish high affinity multivalent interactions by forming specific contacts with multiple sites on the surface of the target molecule. Several of these studies have shown that two or more small molecules that bind to different sites on the surface of a protein with low to moderate affinities can be linked together to produce more complex structures that bind with 3-6 orders higher affinity. Remarkably, this same technology can make a dramatic impact in two highly-divergent fields: detection of biological warfare agents and the treatment of advanced cancer. Using a combination of LLNL capabilities in molecular structure analysis, computational modeling, synthetic chemistry, high-throughput NMR screening of ligand binding, and mass spectrometry of macromolecular complexes, we have designed and begun producing of a number of prototype high-specificity, high-affinity molecules for detecting toxins and pathogens and targeting metastatic cancer cells.

As part of a multi-National Laboratory DOE project, we determined the structures of the targeting and catalytic structural domains of tetanus and botulinum neurotoxin and used these structures to design a set of synthetic, highly robust bidentate molecules that bind to pairs of unique pockets on the surface of the targeting domains of clostridial neurotoxins. The goal of this effort is to create high affinity, highly selective, robust reagents that can be used to detect the unique protein signatures of threat toxins, viruses and bacterial pathogens. Computational methods were used to perform "virtual" screens of large numbers of small molecules for their potential to bind to specific sites on the protein and mass spectrometry and NMR spectroscopy were used to identify the molecules that actually bind. Pairs of the small molecules that were identified that bind to different pockets on the surface of the toxin were then used to synthesize twenty-three bidentate molecules and seven were determined to bind to tetanus neurotoxin (Fig 1).

In a separate effort, similar methods are being used to develop small molecules that bind selectively and with high affinity to a tumor cell receptor found on human lymphomas, HLA-DR10. Crystal structures of four closely related HLA-DR molecules were used to create a homology model of HLA-DR10, and a set of ligands have been identified that bind to two pockets (Fig 2) flanking a region unique to HLA-DR10. Several bidentate reagents have been synthesized, and one (Fig 3) has been shown to compete with an antibody for binding to the unique HLA-DR10 epitope.

Both sets of molecules are being modified through the attachment of biotin, and the final molecules will be tested to determine their affinities and selectivity once this final phase of synthesis is completed. 


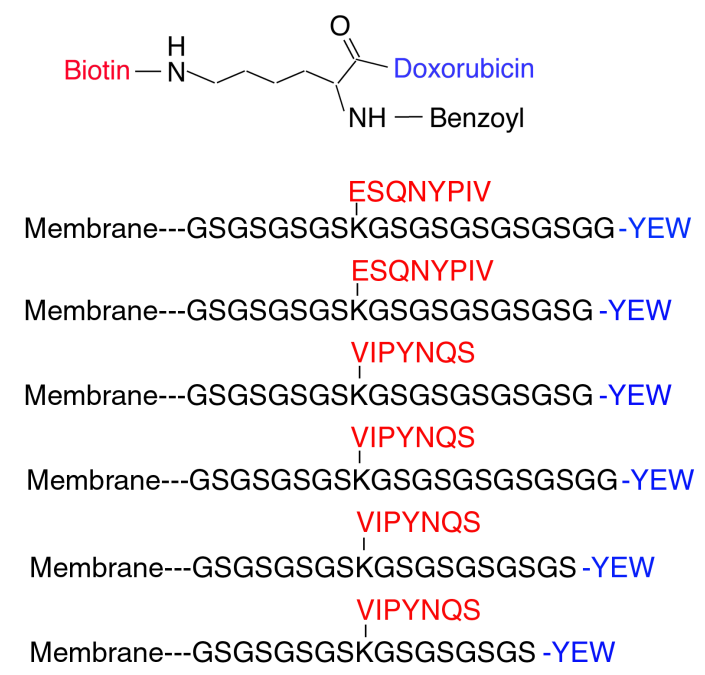

Figure 1. Seven of the twenty three bidentate molecules synthesized were determined to bind to the isolated HLA-DR10 molecules.

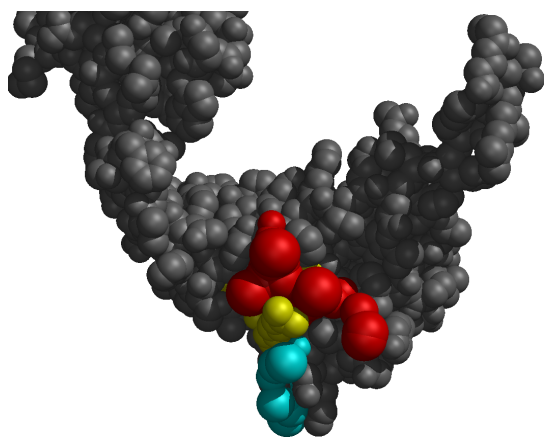

Figure 2. Two pockets on b-subunit of HLA-DR10 targeted for ligand binding are shown filled with red or blue spheres. The arginine residue unique to the tumor cell receptor is shown in yellow.

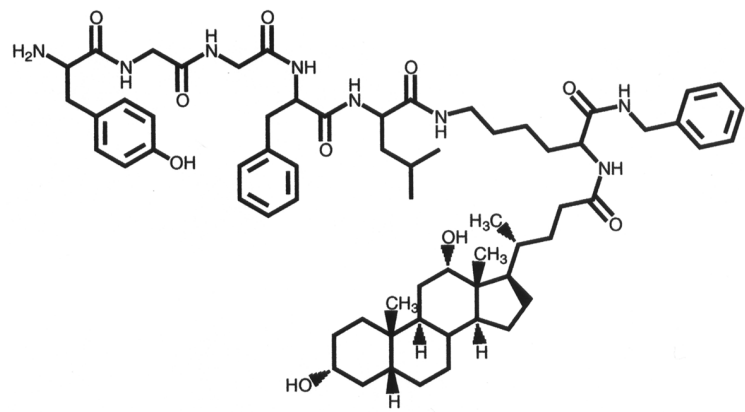

Figure 3. First SHAL synthesized that binds to HLA-DR10 and competes for binding to the epitope recognized by the HLA-DR10 specific antibody Lym-1. 


\author{
Livermore Protein Structure Prediction Center \\ Krzysztof Fidelis, Adam Zemla, Ceslovas Venclovas, Andriy Kryshtafovych
}

\title{
Goals of the Critical Assessment of Protein Structure Prediction (CASP)
}

experiments. At present the structures for only a small percentage of proteins that have been sequenced are known, and the rate at which sequence data is accumulated continues to outpace experimental determination of structure by more than two orders of magnitude. Methods of structure modeling and prediction can help close this gap, for example by extending the structural information to proteins within the same sequence family (modeling by homology). However, fully predictive modeling tools have not yet been developed. An important prerequisite of progress in this direction is an objective and critical method of measuring their success. CASP provides mechanism for such testing. The central idea behind CASP is to test the prediction methods in advance of the experimental structures being released to the public. Objective data on methods performance answers the question of how effective predictive techniques really are, and identifies areas where investment would be most productive. Livermore Protein Structure Prediction Center was established to address the need for an organized, more extensive infrastructure for CASP. The Center played this role for four out of five CASP experiments, beginning with CASP2 in 1996.

Mechanism for the evaluation of protein structure prediction methods. Prediction targets are solicited from among structures about to be solved by crystallography or NMR, and information on their protein sequence and source is made available to predictors. Submissions are accepted within tightly monitored time-windows, prior to release of target structures, and evaluated once target coordinates are available. The results are easily accessible, allowing for viewing, comparison, and analysis of predicted models.

Enhancing prediction evaluation techniques and data analysis tools. We continue to update the still-evolving evaluation criteria and implement the necessary changes in the software, as well as in the web-based visualization of prediction results. In particular we are developing a new measure of structure similarity, capable of a broad range of accurate assessments, from high structure similarity observed in homology modeling to remote structure and protein architecture similarity typical of new fold predictions. We are also improving our evaluation server by integrating the new evaluation techniques so as to enable using CASP criteria for many evaluation tasks, including those outside the main CASP process. 


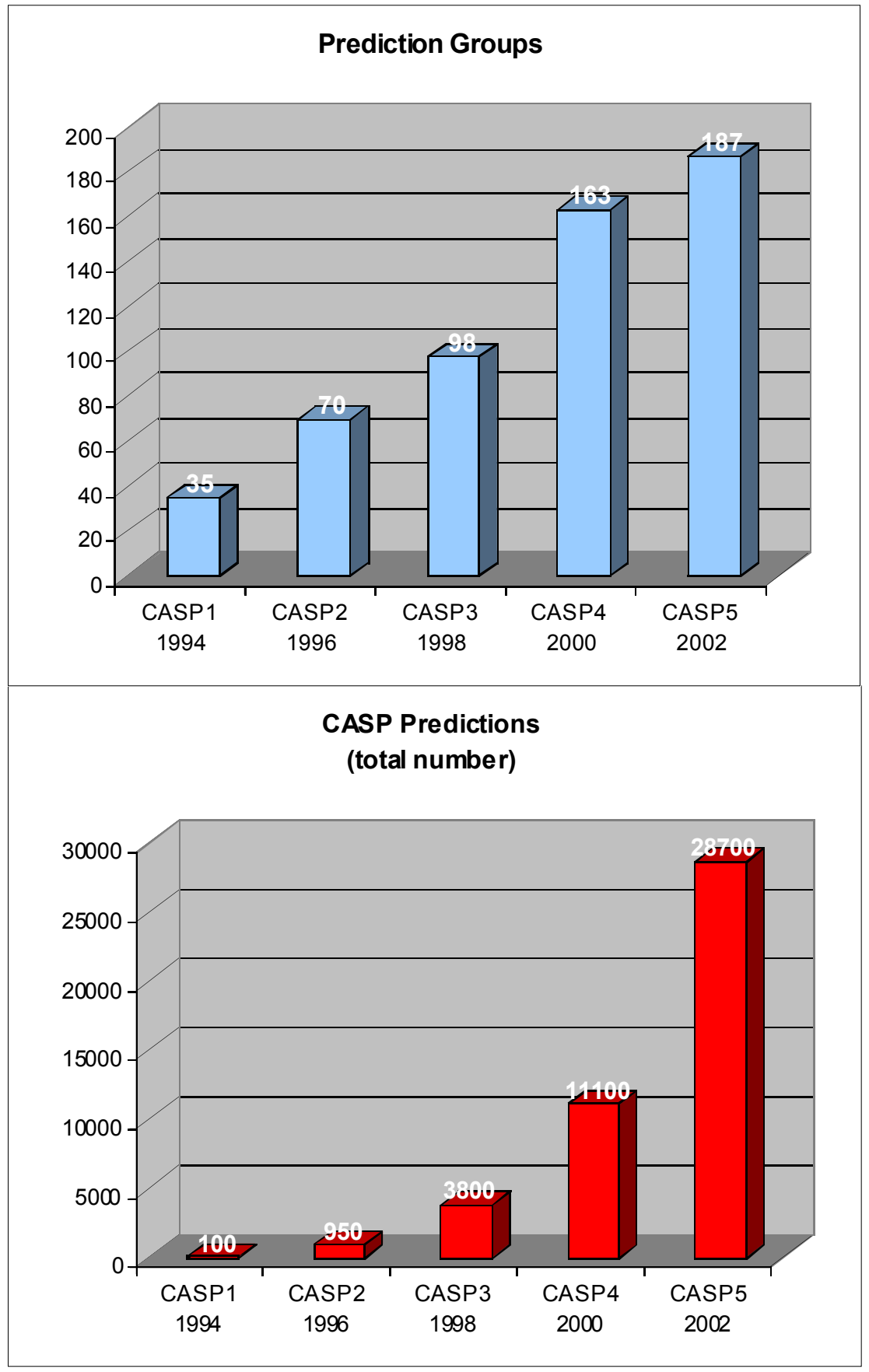

Figure legend: Increase in the number of participating prediction groups and in the total number of submitted predictions over the five CASP large-scale prediction experiments. 


\section{Protein Model Database Initiative}

Alexei Adzhubei and Krzysztof Fidelis

Goal. Protein Model Database would become the worldwide repository of protein structures obtained by modeling and prediction. Presently the Protein Data Bank (PDB) is the sole public database of structures obtained experimentally, by crystallography and nuclear magnetic resonance. Relatively slow and costly experimental determination of protein structure leaves 99 plus percent of all sequenced proteins without the corresponding 3D structure data, opening a significant gap to be filled by modeling and prediction methods. Two main thrusts are envisioned: 1) Results of the high throughput genome scale automated modeling and structure prediction runs, and 2) Results of the high quality supervised modeling involving concerted effort by groups from the modeling and prediction research community. Success of the CASP (Critical Assessment of Protein Structure Prediction) and the TMW (Ten Most Wanted) experiments, experience and considerable recognition gained over the years by the LLNL's Protein Structure Prediction Center make LLNL a strong candidate to host the Protein Model Database.

The CASP process. LLNL was one of the cofounders of the Critical Assessment of Protein Structure Prediction (CASP) large scale prediction experiments in 1994. Two years later it became the site of the Protein Structure Prediction Center created to develop prediction evaluation methods, provide the infrastructure for the CASP process, and organize CASP biannual meetings. In eight years we have seen a major increase in interest in structure prediction. To date five CASP experiments have been held, with both worldwide participation and prediction submission rates increasing substantially: Approximately 35 research groups submitted 100 models in 1994 while over 180 groups submitted 28,700 models in 2002 .

The Ten Most Wanted (TMW) initiative. Along with the significant interest in the structure prediction field came increasing quality of the predicted models. Recognizing this, a proposal was put forward to the prediction community as a whole to address a set of biologically important proteins for which experimental structures are not expected to be solved in the near future. A concerted effort on a relatively small set of proteins and participation of the best modeling groups worldwide are expected to assure the highest presently attainable quality of models. The first round of this initiative, dubbed the "Ten Most Wanted," for the ten selected modeling targets is currently underway. Livermore Prediction Center coordinates this community-wide effort. 


\section{Physical Biosciences Institute}

\section{Michael Colvin}

The emerging disciplines of "systems biology" or "quantitative biology" offer the promise of developing predictive models of biological process that could help interpret and design biological experiments. Fulfilling this promise will depend heavily on new technologies from the physical sciences and advanced computations. LLNL has many scientific and technical capabilities that could allow it to have roles in aspects of this "new biology" that are important to basic biosciences, as well as national security and other DOE missions. Moreover the scientific challenges in this field will be valuable in attracting and retaining the strong multidisciplinary talent.

To help foster the application of physical science techniques in the life sciences, the LLNL University Relations Program has just created a new Physical Bioscience Institute (PBI). The goal of the PBI is to attract and train future talent for LLNL life sciences by creating an incubator for multidisciplinary post-doctoral projects that link LLNL experimental and simulation capabilities to research projects in quantitative biology. To date the PBI has hired seven post-docs who will be participating on projects involving bioscience, physical science and engineering disciplines at LLNL and collaborations with the larger life sciences community. 


\title{
LLNL Nuclear Magnetic Resonance Center for National Security
}

\author{
Monique Cosman
}

Nuclear magnetic resonance (NMR) spectroscopy is a nondestructive, element specific method that since its introduction in the 1950's has revealed new information about the physical, chemical and biological properties of matter. Today, solution-state NMR is used to determine the structures and dynamics of proteins and nucleic acids, as well as screen a library of small molecules for binding to a target receptor in order to design new and better therapeutics. Solid-state NMR is used to analyze materials, such as polymers and semiconductors. High resolution NMR imaging has the potential to screen the effects of drug binding to living cells. Moreover, NMR is being used to perform simple calculations that may someday power an era of quantum computing.

The new NMR center in B151 co-locates a multidisciplinary team of NMR spectroscopists from BBRP and CMS together with a suite of NMR instrumentation with solution-state, solid-state and imaging capabilities. This will allow us to more effectively develop and sustain a balanced, leading-edge research program containing experimental efforts that contribute to the primary missions of LLNL. We are also major participants in a new NIH PO1 grant proposal submitted on November 15, 2002 through UCB (David Wemmer, PI) for the acquisition of a Central California $900 \mathrm{MHz}$ magnet.

Three projects that are relevant to BBRP specifically and involve the national security issue of human health are briefly summarized below.

(1) DNA Adduct/Polymerase Interactions: The ultimate goal is to understand both the overall global and the molecular details of the interactions between polymerases and damaged DNA, and how these interactions correlate with mutational spectra for a specific DNA adduct that may ultimately lead to cancer. Work in progress includes the expression and purification of DinB, a member of the error prone $Y$ family of DNA polymerases and the determination of DNA adduct structures (Figure 1).

(2) Designing molecules to fight bioterrorism and cancer. We are also using and developing NMR methods in rational drug design for applications in designing chemical sensors to detect threat pathogens and toxins and antitumor agents to treat cancers. A paper describing our recent NMR studies of the tetanus toxin ligands has been featured as the October 2002 cover article in Chemical Research in Toxicology (Figure 2). A new NMR competition assay was developed to identify those compounds that bind to the same and different sites as a known reporter ligand

.(3) Antigen structure in an autoimmune disease. Myelin oligodendrocyte glycoprotein (MOG) is a central nervous system (CNS) myelin basic protein that our NMR studies have suggested may lead to multiple sclerosis (MS) by changing its conformational state. Our collaboration with Claude Genain, a leading expert in MS at UCSF, has resulted in one publication in Neurobiology of Disease on the homology modeling of MOG and the mapping of autoantibody epitopes onto the model (Figure 3). Several additional publications are in preparation - 1) on the expression, purification, and activity of labeled MOG(1-117) (extracellular domain) under biologically relevant conditions, 2) studies of the transmembrane domain of MOG(122-150) in bicell and micelle solutions, and 3) the NMR structure of MOG(1-117). 


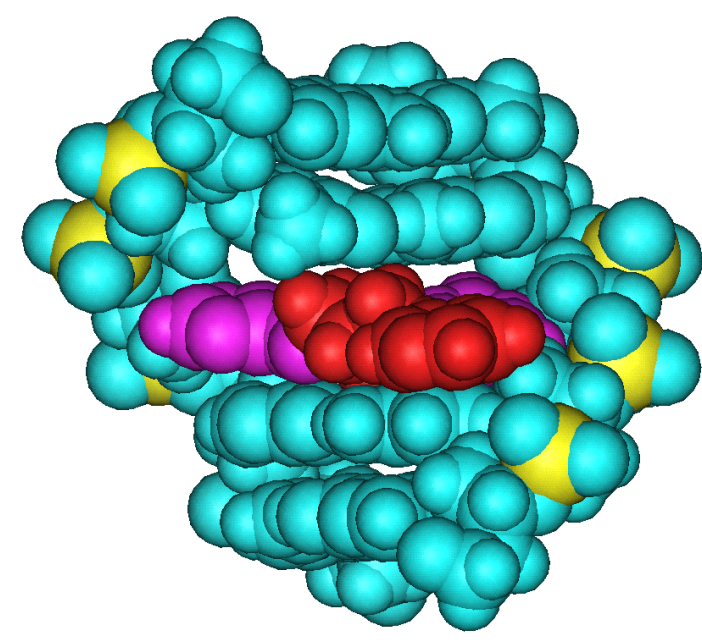

Figure 2: By using a combination of computational methods, mass

spectroscopy, and NMR techniques, an optimal set of small molecules has been identified for use in synthesizing novel bidendate antidotes or detection agents for clostridial neurotoxins, such as tetanus and botulinus. Cosman et al. Chem. Res. Toxicol. 15 1218-1228 (2002)
Figure 1: Structure of the 5mer segment of an 11 mer duplex modified by a pyridyloxobutylating agent that is derived from a metabolically activated tobaccospecific nitrosamine. The adduct formed, $\mathrm{O}^{6}$ [4-oxo-4-(3-pyridyl)butyl]guanine ([POB]dG), can result in mutations that can lead to tumor formation. The POB ligand (in red) is located in the major groove. The modified G-C (in purple) base pair exhibit wobble hydrogen base pairing. Peterson et al, in preparation.

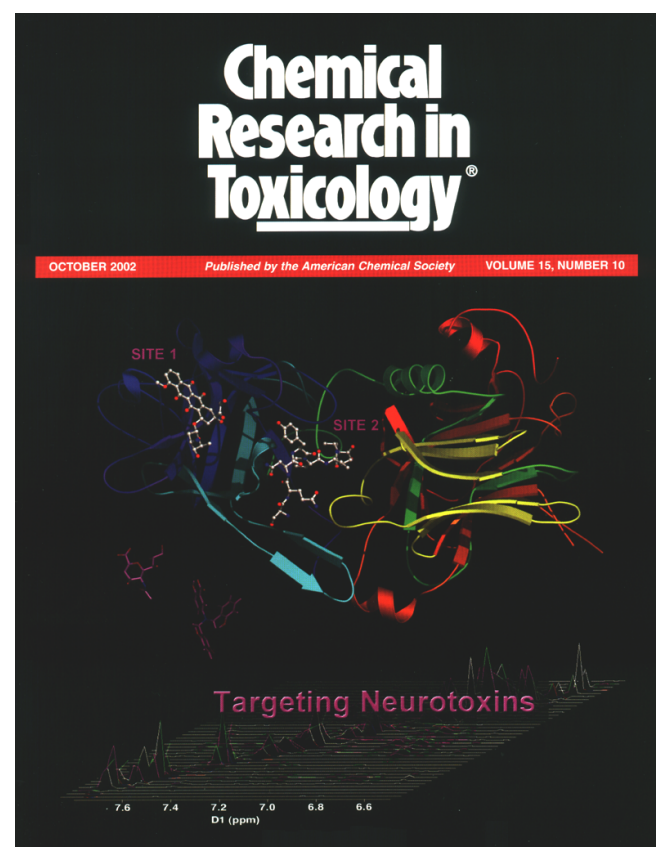

Figure 3: Epitopes identified from rat-MOG(1125)-immunized marmosets are mapped onto the homology model of human MOG(2-120). B cell epitopes are in blue, $\mathrm{T}$ cell epitopes are in green, and regions containing both $\mathrm{B}$ and $\mathrm{T}$ cell epitopes are in yellow. Mesleh et al., Neurobiology of Disease 9, 160-172 (2002). 


\section{Significant Achievements}

Much of the research within the Biology and Biotechnology Research Program crosses organizational boundaries. We have used general science topics as well as scientific groups as subdivisions to highlight the variety of research achievements accomplished during 2002.

\section{Genome Biology}

- JGI sequencing teams contributed to the draft sequence of the genome of the pufferfish, Fugu rubripes, and completed and analyzed draft sequence of the sea squirt, Ciona intestinalis, and several microbial species. Fugu and Ciona genome sequence analysis were the topics to two major articles in the journal Science in 2002.

- The sequence of human chromosome 19 has been finished to high accuracy, and JGI teams are now putting final touches on the sequences of chromosomes $5 \& 16$.

- We generated sequence from a conserved 600kb imprinted gene region in human, mouse, and cow and used comparative genomics approaches to identify conserved regulatory elements including a differentially methylated insulator sequence that may serve as an imprinting-control element for this domain. The insulator sequence is regulated by methylation-dependent binding of transcription factor YY1 in vivo, providing a potentially new regulatory pathway for regulating imprinted gene expression.

- By comparing related genomic regions of human, mouse and rat we discovered a set of species-specific transcription factor genes that arose by recent genomic duplications, and elucidated potential mechanism by which duplicated genes take on new function. The finding of these human- and rodent-specific genes suggests that gene regulation networks are evolving rapidly and are differently configured even between closely related species.

- The I.M.A.G.E. Consortium continues to provide arrayed cDNA resources to the community through a network of distributors. We have arrayed over seven million cDNAs from seven species (1.5 million cDNAs in 2002), resulting in over four million ESTs submitted to Genbank (dbEST) so far.

- As part of the Mammalian Gene Collection (MGC) project, we have re-arrayed over 57,000 (18,000 in 2002) predicted full-length genes and made them available to the research community. The full-length sequences have been submitted to Genbank. At this time $66 \%$ of human and $60 \%$ of mouse known genes have a full-length I.M.A.G.E. clone representative from this project.

- We have updated the IMAGEne sequence clustering program to cluster and align ESTs and known genes from mouse in addition to human. Based on the results of the latest data, $87 \%$ of mouse and $96 \%$ of human known genes have an I.M.A.G.E. clone representative. 


\section{Biodefense}

- Finished three microbial pathogen - or near neighbor - genomes (from the Yersinia, Francisella and Brucella groups) and are finishing another six for use in comparative genomics studies.

- Developed improved protocols for sequencing viral pathogen genomes, and have used these techniques to finish roughly $90 \%$ of four Filoviridae.

- Designed and built a computational system for designing unique DNA detection assays for bacterial and viral pathogen detection, using a whole-genome comparison approach.

- DNA signatures from computational system are now in use by the public health system across the country.

- Demonstrated identification of virulent agents in aerosols using the Autonomous Pathogen Detection System (APDS).

- Demonstrated fully automated operation of the Autonomous Pathogen Detection System in a major public building.

- R\&D 100 Award: For the development of in situ Rolling Circle Amplification single base detection.

- Developed hybrid interference technology for long-term gene silencing without the need for active transfection or transformation of the target cells.

- Developed a novel system to clone in E. coli whole circular plasmids from any source, allowing a "plasmidomics" approach for the study of plasmids from diverse prokaryotes. This was published in FEMS Microbiology Letters.

- Successful recruitment increased our in house expertise in select agents and environmental sampling for Bacillus anthracis and expanded the scope of our studies.

- We are determining the viability of PCR detected organisms.

- Successfully constructed a validated model predictive of virulence of $B$. anthracis in vaccinated animals.

- Characterized the genetic diversity of B. anthracis in North America and correlated this to geographic distribution of environmental factors.

- We examined chromosomal differences between B. anthracis and two close relatives, B. thuringiensis and B. cereus. This was published in Applied and Environmental Microbiology. 
- We are characterizing host-pathogen interactions using human host cells exposed to Yersinia pestis and two near neighbors in order to define a host signature response for presymptomatic detection of plague.

- We are characterizing proteomic changes responsible for virulence of $Y$. pestis and have identified over $70 \%$ of the predicted proteome (in collaboration with PNNL).

- Using an in-house, designed and fabricated, whole-genome array of $Y$. pestis and $Y$. pseudotuberculosis we have carried out global analyses of the transcriptional response of these organisms during growth transition between $26^{\circ} \mathrm{C}$ and $37^{\circ} \mathrm{C}$.

- Using the Y.pestis microarray, we characterized the global transcriptional response that takes place during shift in growth conditions that mimic the environment inside macrophages.

- Determined the global transcriptional response of dendritic cells upon exposure to $Y$. pestis.

\section{Molecular Biophysics}

- A new NMR-based screening method was developed to determine where a ligand is binding on the surface of a protein molecule, enabling more efficient development of multidentate BW detection reagents (Chem. Rev. Tox., Oct. 2002).

- We completed and reported the first 3D NMR structure for a DNA covalently modified by a food mutagen (heterocyclic amine), revealing how structural distortions in DNA by this class of compounds may lead to cancer (Nat. Acad. Sci. Proc., 2001).

- The 3D NMR structure and dynamics characterization of the breast cancer Cterminal domain of DNA Ligase III, a protein important in protein-protein interactions in DNA repair mechanisms, was completed (Biochem., 2001).

- A program (enQC-lator) was developed to simulate a three qubit NMR QC experiment and to evaluate and aid in the design new algorithms for Quantum Computing prior to experimental implementation.

- To test previous NMR data that suggest a conformational switch in the structure of the myelin protein MOG might play a role in the induction of multiple sclerosis, we modeled the 3D structure of MOG and mapped the antibody epitopes onto the surface to show that the conformation change is a plausible explanation for why autoantibodies may recognize and attack self myelin in the disease (Neurobio. Dis., 2002). 
- The process of protein crystallization has been automated and $\sim 100$ proteins produced by the TB Structural Genomics Consortium were processed. Initial crystallization conditions were identified for $>35$ TB proteins, and we refined optimal crystallization conditions for $>10 \mathrm{~TB}$ proteins and participated in the structure determination of 3 novel TB proteins. (Acta Crystallographica D).

- In support of the crystallization facility, we have developed the automated crystal detection software CrysFind.

- Working with others, we initiated proteomics and structural genomics studies of 200 putative virulence factors from $Y$. pestis identified by differential microarray analysis and comparative genomics. We have cloned $\sim 85 \%$ of the targeted genes, screened the genes for expression yield, purified three $Y$. pestis proteins with unknown structures, and have initiated crystallization trials with these proteins.

- In support of the $Y$. pestis proteomics effort, we have initiated the development (in collaboration with others) of a Laboratory Information Management System (LIMS) that includes a homology modeling engine that maintains a best current homology based model for each putative $Y$. pestis virulence gene.

- We have synthesized 23 synthetic bidentate molecules designed to detect clostridial neurotoxins and have determined that 7 of these sequences bind to the targeting domain of tetanus neurotoxin.

- Using the protein signature pipeline, we have identified (in collaboration with others) unique protein signatures for seven viral, bacterial and spore proteins. A set of signatures for the West Nile Virus coat protein were used to test the feasibility of to create pathogen specific monoclonal antibodies that bind to these signatures, and hybridoma clones producing antibody have been obtained for three of the six sequences tested.

- The first bidentate synthetic molecule targeting the tumor cell receptor HLADR10 has been designed and synthesized. Preliminary competition experiments indicate it competes with an antibody for binding to the correct site on lymphoma cells in culture.

- A single molecule technique called Antibunching was developed for determining the number of fluorochromes that are attached to an individual DNA or protein molecule. This technique is being used in a number of single molecule experiments to examine the biophysics of polymerase/repair protein-DNA interactions. 


\section{DNA repair}

- Constructed a Fanconi anemia FancG gene knockout mutant CHO in cells and prepared isogenic gene-complemented control cells

- Showed that the FancG mutant cells are sensitive to a broad spectrum of DNAdamaging agents but have very little sensitivity to ionizing radiation.

- Showed that the FancG mutant cells have elevated reactive oxidative species, an increase in the $\mathrm{G} 2$ phase of the cell cycle, and a reduced mutation frequency at the HPRT locus.

- Demonstrated that the FancG mutant cells have normal Rad51 nuclear foci induced by ionizing radiation, and abnormally high levels of nuclear foci after exposure to alkylating agents.

- Prepared a CHO cell line in which the first allele of the $R A D 51 C$ gene is knocked out and genetically engineered a means of conditionally expressing the $R A D 51 C$ null mutation once the second allele is knocked out.

- Showed that mice having a very low level of XRCC1 protein ( $\leq 10 \%$ of normal), which is involved in base excision repair, can still undergo normal development and postnatal growth; the absence of protein causes early embryonic lethality.

- Determined that RAD51B, RAD51C, RAD51D and XRCC2 form a stable, protein complex in vivo, devoid of RAD51.

- Used yeast two-hybrid analysis and molecular modeling to map the interaction of the RAD51B-RAD51C interaction.

- Generated stable cell lines which over-express wild-type and mutant RAD51B and RAD51C proteins.

- Initiated two external collaborations with industrial partners to produce recombinant human proteins in a miniaturized, baculovirus-based system and received a UC Discovery award to support this work.

- Isolated and overexpressed hamster Rad52 cDNA in xrcc2 hamster mutant irs1 cells, conferring partial survival resistance to ionizing radiation. The irs 1 cells that overexpressed Rad52 showed decreased chromatid aberrations and increased capability of Rad51 focus formation induced by ionizing radiation, suggesting an overlapping function of XRCC2 with Rad52 in homologous recombination. 
- Conducted protein interaction studies of domains of human XRCC2 and Rad51D, demonstrating that the RecA-like core regions in both XRCC2 and Rad51D are essential for the interaction between the two proteins. These finding provide new information of the structural and functional interactions between the XRCC2 and Rad51D proteins.

- Have expressed and purified full-length and truncated forms of human XRCC2 and Rad51D proteins expressed in E. coli for use in characterizing their biochemical activities and for protein structure analysis.

\section{Mutagenesis and carcinogenesis}

- In our continuing analysis of melanoma in LLNL employees, we have determined that the melanoma surveillance effort begun in 1984 is associated with zero melanoma mortality in the period from 1984 to 1997. This is a significant reduction below expected mortality based on California mortality rates.

- Determined that household pets are exposed to heterocyclic amines in commercial pet foods, suggesting the need to investigate their carcinogenic effects in exposed animals.

- Developed TOF-SIMS mass spectrometry to detect carcinogens in nanoliter-sized samples for application to human nipple aspirate fluids.

- Developed an in vitro digestion method to determine the effect of digestion parameters and other foods in the diet on the bioavailability of heterocyclic amines. Using this model, we showed that both the doneness of the meat and the presence of other foods in the gastrointestinal tract change the release of heterocyclic amines from the meat matrix.

- Screened 10 heterocyclic amines that are ubiquitous food mutagens in an estrogen receptor activation assay and determined they have the potential to be endocrine disruptors.

- Showed that a common complementary and alternative medicinal agent, used by cancer survivors to treat disease and prevent recurrence, stimulates breast cell and tumor growth using both in vitro and in vivo assays.

- Applied TOF-SIMS mass spectrometry to image the presence of a mammary carcinogen in human breast cancer cells to investigate intra-cellular concentrations. 
- Conducted studies to establish which agents prevent DNA adduct formation by the dietary carcinogen PhIP. Found that the isothiocyanate PEITC and chlorophyllin both reduce adduct formation in the prostate, hence might be useful in prostate cancer prevention. In collaboration with Dr. Ralph deVere White at UCD Medical Center, we are now establishing a preclinical model of prostate cancer which will be used to test the utility of PEITC and chlorophyllin in preventing prostate cancer incidence.

- Established that PhIP forms adducts in human colon and that adduct levels are highly variable between individuals (80\% variation was seen in DNA adduct levels in the colon of 10 volunteers), in collaboration with Dr. N.P. Lang (University of Arkansas for Medical Sciences). We also showed that the albumin adduct level in the blood may be a useful biomarker of PhIP exposure for use in molecular epidemiology studies.

\section{Genetic Susceptibility}

- Investigated the relationships between genetic variation and risk in the genes of the Base Excision Repair (BER) pathway. We found seven single nucleotide polymorphisms (SNPs) that explain $29 \%$ of the inter-individual variation in endogenous damage, as measured by the level of endogenous damage and amount of damage removed early after exposure to ionizing radiation using the alkaline comet assay. An overlapping set of five SNPs explained $18 \%$ of inter-individual variation in repair of radiation-induced damage. These SNPs are high-priority candidates for analysis of protein function and inclusion in molecular cancer epidemiology studies.

- Identified an average of over five amino acid substitution variants per gene in the systematic screening of $\sim 80$ DNA repair genes for sequence variants in a set of 90 healthy individuals representing the ethnic diversity of the U.S. population. These variants are expected to be the molecular and biochemical basis for the welldocumented association of the reduced repair capacity phenotypes with cancer risk. Computational algorithms predict that $25 \%$ of the variants should dramatically impact protein function and another $25 \%$ of the substitutions will have a moderate impact on function. The amino acid substitutions predicted to have a negative impact on the normal structure and activity of these proteins account for $\sim 50 \%$ of the genetic variation among individuals. 
- Demonstrated that the SIFT algorithm correctly predicted the impact of 6 of 7 amino acid substitutions on the biochemical activity of APE1, including 3 of the 4 variants retaining less than $50 \%$ of normal activity. The amino acid substitutions identified as significantly associated with reduced BER capacity phenotype were predicted to have impaired activity. One challenge for molecular epidemiology studies is selection of the subset of variants for genotyping. The polymorphic alleles predicted to impact protein structure and activity should be priority candidates for studies of individual genetic susceptibility to exposure and variation in the risk of sporadic cancer in the general population.

\section{Reproductive and Developmental Biology}

- Showed that a man's age has a negative affect on the quality of his sperm, even among healthy workers and retirees. In a study of approximately 100 men aged 20 to 80 , the quality of sperm motion began to decline as early as the third decade of life and continued to gradually decline with increasing age.

- Demonstrated that the frequency of sperm with mutations in the achondroplasia gene increases with age, but not at the rate predicted by the age-related increase of children with dwarfism. This data suggest that there are complex factors involved in the paternal transmission of this gene mutations via sperm.

- Showed that the frequencies of aneuploid sperm remained constant over time in young healthy men, but that men different significantly from each other in the baseline frequencies. There were significant correlations between the frequency of aneuploidy in sperm and blood cells, suggesting that men with higher than normal frequencies of aneuploidy in both cell types may be at elevated risk for both somatic disease and heritable defects.

- Demonstrated that chemotherapeutic drugs induced transient increases in the proportion of sperm associated with all the major human aneuploidy syndromes including Down, Klinefelter, Turner, triple X, XYY, and Edward syndromes, but these effects were transient and did not persist beyond six months after treatment.

- Developed a sperm FISH assay to detect chromosome structural aberrations in mouse sperm. Comparison of the results between mice and men show that the spontaneous frequencies of sperm with chromosome structural aberrations are five-fold higher in men. 
- Investigated the effects of the zygotic repair of DNA double stranded breaks in sperm exposed to ionizing radiation using chromosome painting after mating irradiated males with female mice repair-deficient in either DNA-PK (non-homologous end joining) or Rad54 (homologous recombination). The results showed a doubling of the frequencies of paternally transmitted chromosomal aberrations when DNA-PKdeficient females were used, while a modest increase was seen when Rad54-deficient females were used. These results suggest that ionizing radiation-induced sperm DNA lesions are repaired in the egg after fertilization and that the non-homologous end joining pathway may play a greater role than the homologous recombination pathway.

- Applied a novel nano-indentation scanning method to characterize the hardness and elasticity profiles across anatomical locations during the formation of the exoskeleton in larval and pupal stages of the fruit fly. This study was the first demonstration of the application of nano-indentation for measuring hardness and elasticity in a live animal.

\section{Radionuclide and Radiation Biology}

- Established a method for preparing samples for analysis of tritium content by Accelerator Mass Spectrometry in collaboration with Marina-Chiarappa-Zucca (C\&MS) and Adam Love (UCB). This method was used to analyze tree rings and hence establish environmental tritium exposures.

- Conducted a genome-scale survey of the effects of low dose ionizing radiation on gene expression changes in the brain of irradiated mice. Low-dose exposure resulted in early changes in genes involved in signal transduction, ion regulation and synaptic signaling. Late changes involved a number of metabolic pathways including myelin and protein synthesis. There were also changes in expression of genes involved in stress response, cell-cycle control, and DNA synthesis/repair. The brain appears to respond to low dose irradiation by evoking protective as well as reparative mechanism while down-regulating genes involved in neural signaling.

- Identified and characterized specific genes whose expression patterns were associated with adaptive response, which occurs when a low-dose of ionizing radiation reduces the damage from a subsequent higher dose of irradiation. We found that cytogenetic measured radioadaptive responses can be attributed to increased expression of DNA damage sensing genes, while genes that drive cellular proliferation are downregulated.

- Co-developed a web-based technology for querying of multiple bioinformatics sources to investigate the roles of co-regulation of genes in various types of radiation responses. Our web-based technology provides the biologist with a quickly adaptable way to identify genes and functional pathways that are coincidentally related to gene expression patterns. 


\section{Computational and Systems Biology}

- Provided one project and one core for a successful NIH P01 grant on Heterocyclic Amine Food Mutagens

- Started a collaboration with the new UCD Cancer Center to use molecular modeling to assist in the development of pre-targeted radioimmunotherapeutics. This project constituted a core in a NIH Program Project grant that was site-visited in January 2003, final score pending.

- Created a protein secondary structure prediction facility, based on gathering multiple predictions and creating a consensus prediction (aka meta-prediction).

- Analyzed molecular dynamics (MD) simulations of mutants of the human DNA repair protein Ape1, finding an empirical relationship between increased motion in the simulations and the experimentally measured decrease in thermal stability.

- Created models of the RAD51 DNA repair proteins (RAD51B, RAD51C, RAD51D, $\mathrm{XRCC} 2, \mathrm{XRCC} 3$ ) and used these to guide experiments involving yeast two-hybrid expression as well as site-directed mutagenesis.

- Organized the fifth Critical Assessment of Protein Structure Prediction (CASP5) large-scale experiment dedicated to advancement of the protein structure prediction field. CASP5 saw substantial advancement in quality of predictions as well as increase in participation.

- Put forward an initiative to create a Protein Model Database, complementary to the Protein Databank (PDB) and encompassing structures derived theoretically rather than by experiment.

- Started a new research project dedicated to gene regulation analysis using knowledge discovery methods.

- Published a first principles molecular dynamics simulation on the hydrated magnesium ion in Chemical Physics Letters. This paper is now cited by other groups as the standard way to analyze first principles molecular dynamics simulations of ions. 


\section{Bioinformatics}

- Successful support of BASIS team system development and deployments to the Olympics and elsewhere.

- $\quad$ Support of the JGI production sequencing ramp to over 1 billion high-quality basepairs per month.

- Contributions to Ciona, Fugu, and other whole-genome analyses and annotation jamborees, and subsequent Science publications.

- Development and testing of CDC-validated microbial pathogen DNA signatures,

- Collaborative efforts underway with USDA, USAMRIDID, UCD, etc., and initiation of new CBNP efforts to develop protein signatures for many other bacteria and viruses.

- Continuous support and improvement to I.M.A.G.E. project, with a recent release of IMAGEne version 4.2. 


\subsection{Program Organization, Facilities and Resources}

\section{Organizational Structure}

During 2001, the staff and management of BBRP worked together to develop new units that reflect distinct areas of interest of the Program. The Divisions include scientific areas that have organizational structure that is well suited for moving into the post-genomics era and the new opportunities and needs in homeland security. In addition, several groups have been formed in areas with an active and strong interest for the Program as well as growing areas of expertise. They include:

\section{Genome Biology Division \\ Computational and Systems Biology Division \\ Biodefense Division \\ Health Effect Genetics Division \\ Molecular Biophysics Group \\ Environmental Microbiology Group \\ Bioinformatics Group}

This new organization is outlined in Figure 1 on the following page. One of these new units, Environmental Microbiology, is a new thrust area, and we are actively recruiting for a strong leader to bring this expertise to this laboratory. The new administrative structure both depends on and builds on BBRP's tradition of 'invisible' organizational boundaries; e.g. scientists can work together across these boundaries in a highly interactive fashion to work with colleagues within the program.

Within the BBRP Program Office, Alan Casamajor acts as Assistant to the Associate Director (AAD) for Facilities and Safety. The AAD for Resource Management, Cynthia Gardner, is responsible for our business operations and finances. Peggy Biggs continues to serve as the Program Administrator and manages the administrative functions of the Program. 


\section{Biology and Biotechnology Research Program}

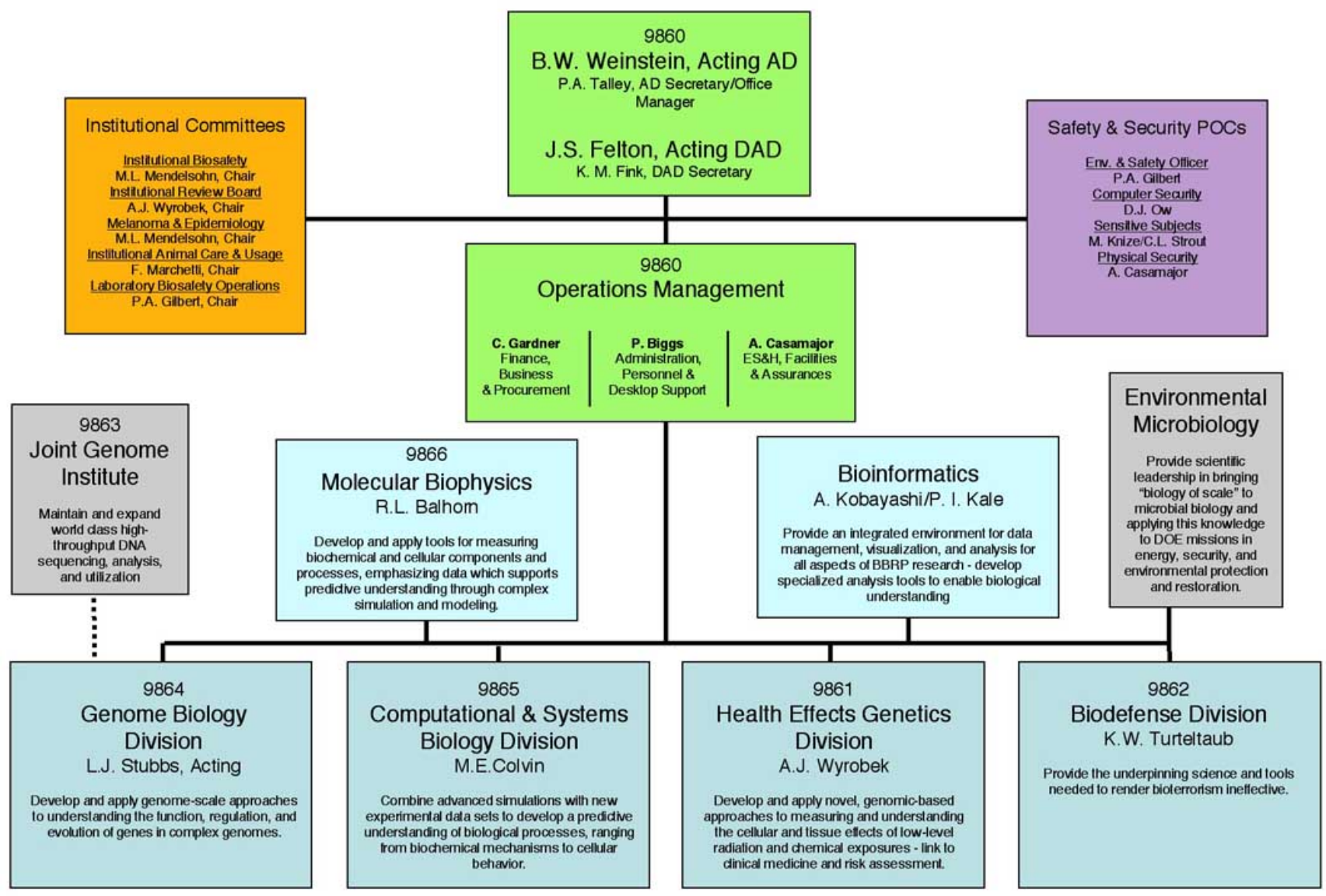

Figure 1. BBRP Organizational Chart, November, 2002 


\section{Program Reviews and Advisory Committee}

A variety of methods are used to assess the quality of our science and technology. At the project level, each federally funded effort is subject to a peer review process specific to its sponsor. For NIH and DOE, peer review is required for initial funding and for renewal. Every project is externally reviewed at least once every three years. At the program level, we undergo a bi-annual internal review by the LLNL Director, several of the Associate Directors, other LLNL staff, and laboratory consultants. This review focuses on strategic planning, future scientific directions, intra-laboratory interactions, and workforce issues. BBRP's Laboratory Directed Research is reviewed both in BBRP and by an LLNL-wide committee. Our BBRP Advisory Committee meets yearly to review the entire program on a three-year cycle. The membership on the Advisory Committee is shown in Table 1. 2001 was Dr. Cantor's first year as chair of the Advisory Committee.

Table 1. Program Review Committee

Biology and Biotechnology Research Program Advisory Committee, 2002

\author{
Charles R. Cantor \\ Gilbert Chu \\ Hsing-Jien Kung \\ Michael Levitt \\ Barbara Meyer \\ Stephen A. Morse \\ Richard M. Myers \\ Frederick A. Murphy \\ Kenneth H. Nealson \\ David A. Relman \\ Snorri Thorgeirsson \\ James M. Tiedge \\ Barbara J. Wold
}

\author{
Sequenom, Inc., Chair \\ Stanford University Medical School \\ University of California, Davis Medical Center \\ Stanford University \\ University of California, Berkeley \\ Centers for Disease Control and Prevention \\ Stanford University School of Medicine \\ University of California, Davis \\ Jet Propulsion Laboratory \\ Stanford University / Palo Alto Health Care \\ National Cancer Institute \\ Michigan State University \\ California Institute of Technology
}

Lastly, the University of California, our contractor, conducts annual program reviews. The Science and Technology Council composed primarily of university faculty and appointed by the University President reviews the quality of science conducted at UC's three national laboratories. This Council meets with laboratory staff at least annually and receives written input from the Program Advisory Committee. 


\section{Budget Information}

We draw upon several funding sources for our Program. While the Department of Energy remains our primary sponsor, in the past several years we have attracted a diverse assortment of funding sources. Funding amounts for each category are detailed in Table 2. The percentage funding by major funding source is shown in Figure 2. Appendix V details funding from DOE as well as non-DOE sources and from the LLNL Lab Directed Research and Development Program.

Table 2. Current funding sources

\begin{tabular}{|c|c|c|}
\hline Sponsor & $\mathbf{K \$}$ & Funding \% \\
\hline $\begin{array}{l}\text { Dept. of Energy, Office of } \\
\text { Science/Office of Biological \& } \\
\text { Environmental Research }\end{array}$ & 16,847 & 34.8 \\
\hline $\begin{array}{l}\text { Dept. of Energy, Office of Non- } \\
\text { Proliferation and National } \\
\text { Security }\end{array}$ & 16,434 & 33.9 \\
\hline Dept. of Energy, ASCR & 447 & 0.9 \\
\hline $\begin{array}{l}\text { National Institutes of Health } \\
\text { (four institutes) }\end{array}$ & 5,845 & 12.1 \\
\hline Los Alamos National Laboratory & 797 & 1.6 \\
\hline Lawrence Berkeley Laboratory & 133 & 0.3 \\
\hline Battelle & 212 & 0.4 \\
\hline $\begin{array}{l}\text { LLNL Laboratory Directed } \\
\text { Research and Development }\end{array}$ & 4,527 & 9.3 \\
\hline $\begin{array}{l}\text { LLNL General and } \\
\text { Administrative }\end{array}$ & 219 & 0.5 \\
\hline Army & 95 & 0.2 \\
\hline DARPA & 308 & 0.6 \\
\hline Federal, Other & 1,617 & 3.3 \\
\hline $\begin{array}{l}\text { University of California, } \\
\text { Berkeley }\end{array}$ & 263 & 0.5 \\
\hline $\begin{array}{l}\text { University of California, Breast } \\
\text { Cancer Research Program }\end{array}$ & 162 & 0.3 \\
\hline $\begin{array}{l}\text { University of California, UC } \\
\text { Discovery Grants }\end{array}$ & 32 & 0.1 \\
\hline Sloan Kettering Hospital & 113 & 0.2 \\
\hline University of Texas & 15 & 0.0 \\
\hline Industry & 385 & 0.8 \\
\hline TOTAL & 48,452 & 100.0 \\
\hline
\end{tabular}




\section{Relative funding soprces by percentile of total}

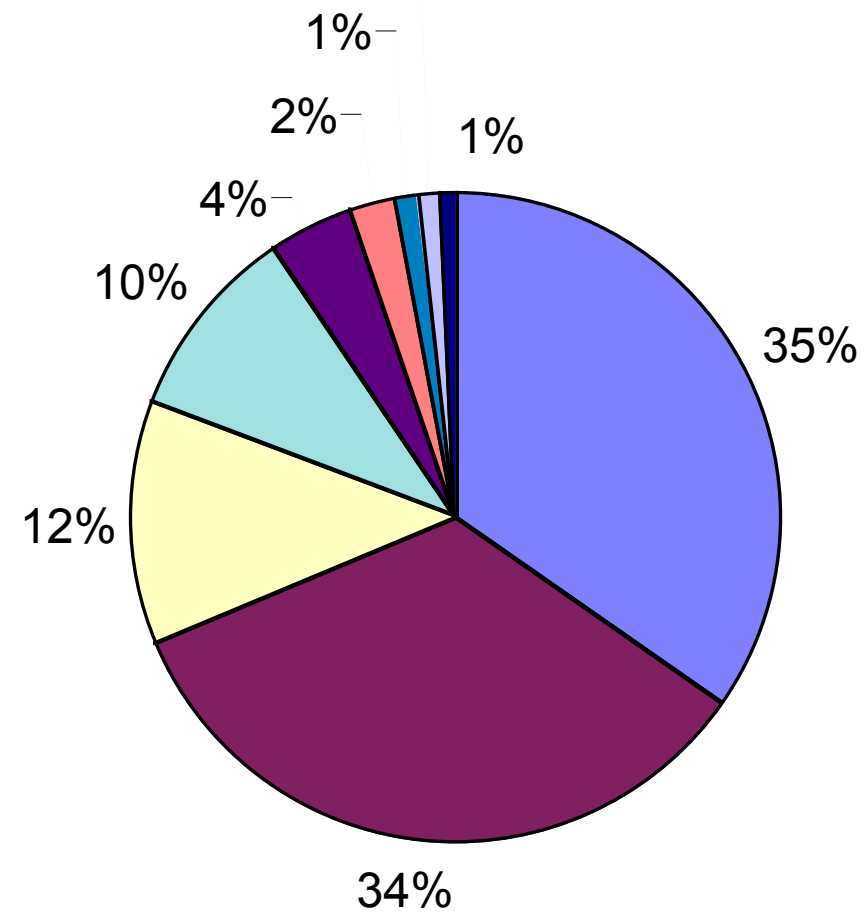

\begin{tabular}{lll}
\hline DOE/OS & $\square$ DOE/ONNS & $\square$ NIH \\
$\square$ LDRD \& G\&A & $\square$ Other Federal & $\square$ DOE/Other Labs \\
$\square$ Other & $\square$ Universities & $\square$ DOE/ASCR
\end{tabular}

Figure 2. Relative funding sources by percentile of total 


\section{Personnel Update}

We draw from a diverse talent pool and facilitate staff advancement through formal training and education programs, self-training, and mentoring. Table 3 presents a snapshot of the BBRP personnel by category. Additional information including a roster of principal investigators and their extramural activities is available in Appendices I and II.

Table 3. Staff by Category - October 2002

\begin{tabular}{|lrrr|}
\hline \multicolumn{1}{|c}{ Personnel } & FY 2001 & FY 2002 & FY 2003 (est) \\
\hline Principal Investigators & 32 & 30 & 25 \\
Other Scientific Staff & 99 & 91 & 107 \\
Technicians & 33 & 36 & 32 \\
Post- Doctorates & 11 & 17 & 25 \\
Graduate Students & 4 & 5 & 8 \\
Undergraduates & 31 & 32 & 33 \\
\hline Total Scientific Personnel & $\mathbf{2 1 0}$ & $\mathbf{2 1 1}$ & $\mathbf{2 3 0}$ \\
\hline Professional Admin. & 11 & 10 & 12 \\
Clerical Admin. Support & 18 & 19 & 19 \\
\hline Total Admin. Personnel & $\mathbf{2 9}$ & $\mathbf{2 9}$ & $\mathbf{3 1}$ \\
\hline TOTAL & $\mathbf{2 3 9}$ & $\mathbf{2 4 0}$ & $\mathbf{2 6 1}$ \\
\hline
\end{tabular}

The Biology and Biotechnology Research Program provides educational and professional training opportunities for their staff, as well as to a wide array of students and faculty. The research and work experiences are designed to enhance the quality of science education at all levels and encourages diversity among people pursuing careers in the biomedical sciences. The programs integrate students and faculty into ongoing research projects and provide opportunities for them to expand their scientific and technical knowledge. The programs encourage students to continue their education in science. The summer programs allow students and faculty to extend and refresh their training and knowledge of areas of current research, and hence increase their ability to encourage students to pursue careers in science. 
Science and Education Research Semester (SERS). This program, jointly funded by DOE and LLNL, provides undergraduates an opportunity to conduct an extended research project as a member of an ongoing research program for an academic semester.

Student Technology Experience Program (STEP). This program provides meaningful work experience to high school and college students, to encourage them to pursue further education in science, engineering or business.

Biology \& Biotechnology Research Student Technical Program. This program is designed to provide opportunities for undergraduate college students to pursue a specific research project relevant to their studies.

Student Participating Guests. These students use lab facilities and/or participate in lab work as part of their academic studies for high school, an undergraduate, or graduate degree.

Participating Teacher/Guests. These teachers use lab facilities and/or participate in lab work to keep abreast of current research and improve classroom instruction.

\section{Summer Programs}

Summer Research Internship Program. This program matches teachers with research projects where they learn about new areas of science and technology and identify materials that can be incorporated in their curricula.

LLNL Summer Employment Program. This program coordinates the summer employment opportunities for students throughout the Laboratory.

Associated Western Universities Summer Program (AWU). This cooperative research program promotes and coordinates research and training in energy-related science and engineering for faculty and students of the Associated Western Universities. 


\section{Facilities}

The major building housing the Biology and Biotechnology Research program is a 68,000 gross square foot, one-story structure containing 83 offices (12,400 sq. ft.), 55 laboratories (24,900 sq. ft.), auditorium, stock room, and administrative offices. Other laboratories (17,500 sq. ft.) and offices $(11,000$ sq. ft.) are located in fourteen nearby buildings and trailers, including special facilities for housing small animals, laboratories for handling virulent pathogens, a radiation exposure facility (a sealed 4,260 Ci ${ }^{137} \mathrm{Cs}$ source), an analytical chemistry laboratory, x-ray diffraction systems, NMR spectrometer, and a high-level carcinogen laboratory (see Table 4).

BBRP is projected to grow at a rate of $5 \%$ per year for the next several years and to develop new areas of research involving work with pathogenic microbes. We are midway in a procurement for adding approximately $1050 \mathrm{sq}$. ft. of laboratory space at Biosafety Level 3. This new facility would provide workspace for two funded activities that are currently using BSL3 facilities at remote locations, and would improve access to additional research dollars in the bio-defense area. We are also exploring options of adaptive reuse of existing buildings at LLNL and new construction to provide for nearterm program expansion.

Table 4. BBRP Facilities

\begin{tabular}{llrr}
\hline Facility & \multicolumn{1}{c}{ Use } & $\begin{array}{r}\text { Office } \\
\text { (Sq.ft.) }\end{array}$ & $\begin{array}{r}\text { Laboratory } \\
\text { (Sq.ft.) }\end{array}$ \\
\hline Bldg. 361 & laboratory \& office & 12,382 & 24,863 \\
Bldg. 362 & laboratory \& office & 633 & 1,937 \\
Bldg. 363 & laboratory & 0 & 1,119 \\
Bldg. 364 & animal care \& laboratory & 0 & 7,057 \\
Bldg. 365 & laboratory \& office & 188 & 2,969 \\
Bldg. 366 & laboratory \& office & 344 & 1,601 \\
Bldg. 367 & office & 305 & 0 \\
Bldg. 373 & storage & 0 & 0 \\
Bldg. 376 & shop \& office & 90 & 0 \\
Bldg. 377 & laboratory \& office & 349 & 2,823 \\
Trlr 3629 & office & 1,482 & 0 \\
Trlr 3649 & library \& computations & 0 & 0 \\
Trlr 3703 & office & 6,469 & 0 \\
Ttlr 3751 & office & 1,708 & 0 \\
Trlr 3777 & office & 4,610 & 0 \\
\hline & & $\mathbf{2 8 , 7 5 7}$ & $\mathbf{4 2 , 3 6 9}$
\end{tabular}




\section{Compliance with Federal Regulations}

Lawrence Livermore National Laboratory has a long standing tradition of concern for the welfare of animals used in research, in the protection and confidentiality of human subjects, and in the careful use of biohazardous materials and biological organisms. Permanent institutional committees supported by the laboratory exist in each area. The Laboratory Director appoints the chair of each committee.

Since 1973, the Animal Care Facility has been in full compliance with the Animal Welfare Act, the U.S. Public Health Service, the National Institutes of Health, the Office of Laboratory Animal Welfare, and the University of California regulations governing the use of animals. In 1976 we established an active Institutional Animal Care and Use Committee, currently chaired by Francesco Marchetti, whose membership has representatives from our scientific staff and the local community. Our Animal Welfare Assurance, which dictates the institutional compliance requirements for LLNL, was recently renewed and is effective until July 31,2007. We are also fully accredited by the Association for the Assessment and Accreditation of Laboratory Animal Care International. Our accreditation has been recently renewed and is in effect until 2005.

The Committee on Humans Subjects Research (officially known as the LLNL Institutional Review Board) was formed in 1974 to serve all directorates and programs at LLNL. Since its inception, the conduct of the committee has been in full compliance with DOE, DHHS and University regulations. LLNL has maintained a Multiple Project Assurance (MPA) with the Department of Health and Human Services since 1983. The current MPA, which dictates the institutional compliance requirements for LLNL, was renewed in August of 1998 and is effective until August 31, 2003. The IRB is composed of scientific and non-scientific, as well as institutional and non-institutional members, and is chaired by Andrew J. Wyrobek. The IRB operates under provisions of the Code of Federal Regulations, 10 CFR Part 745, revised June 1991.

The Institutional Biosafety Committee (IBC) was established at Lawrence Livermore National Laboratory in 1991 to ensure compliance with regulations concerning research with either recombinant DNA or human, animal, and plant pathogens. Currently the regulations are the NIH Guidelines for Research Involving Recombinant DNA Molecules, (http://www4.od.nih.gov/oba) and Biosafety in Microbiological and Biomedical Laboratories, Center for Diseaee Control, US DHHS, $4^{\text {th }}$ edition, 1999. Secondarily, since 1998, the IBC is the registrar and administrator for LLNL under the Laboratory Registration and Select Agent Transfer Program of CDC. In its primary role, the IBC must approve all activities in the cited subject areas prior to commencement of research. The committee is registered with the NIH Office of Recombinant DNA Activities, and consists of scientists, physicians, lawyers, and community members. It is cochaired by Mortimer L. Mendelsohn and Rodney L. Balhorn 


\subsection{Appendices}

Appendix I: Biology and Biotechnology Research Program Senior Staff

Principal Investigators / Project Managers

\begin{tabular}{|c|c|c|c|}
\hline Albala, Joanna S. & $\mathrm{PhD}$ & Yeshiva University, Bronx, NY & Pathology \\
\hline Balhorn, Rodney L. & $\mathrm{PhD}$ & University of Iowa, Iowa City & Biochemistry/Chem \\
\hline Christian, Allen & $\mathrm{PhD}$ & Colorado State University, Ft Collins & Chemical Engineering \\
\hline Coleman, Matt & $\mathrm{PhD}$ & Boston University, Boston & Molecular Biology \\
\hline Colvin, Michael E. & $\mathrm{PhD}$ & University of California, Berkeley & Chemistry \\
\hline Cosman, Monique & $\mathrm{PhD}$ & New York University, New York & Physical Chemistry \\
\hline Dingley, Karen & $\mathrm{PhD}$ & York University, England & $\begin{array}{l}\text { Biochemistry/ Environmental } \\
\text { Toxicology }\end{array}$ \\
\hline Felton, James S. & $\mathrm{PhD}$ & State Univ. of New York, Buffalo & Molecular Biology; Zoology \\
\hline Fidelis, Krzysztof A. & $\mathrm{PhD}$ & University of Oklahoma, Tulsa & Physical Chemistry \\
\hline Garcia, Emilio & $\mathrm{PhD}$ & University of California, Davis & Microbiology \\
\hline Knize, Mark & BA & Calif. State Univ. Stanislaus, Turlock & Biology \\
\hline Kulp, Kris & $\mathrm{PhD}$ & University of California, Davis & Pharmacology \\
\hline Langlois, Richard G. & $\mathrm{PhD}$ & Columbia Univ, New York, NY; UCB & Chemistry \\
\hline Liu, Nan & $\mathrm{PhD}$ & St Andrews University, UK & Medicine \\
\hline Marchetti, Francesco & $\mathrm{PhD}$ & University of Rome, Italy & Biological Sciences \\
\hline McCutchen-Maloney, S. & $\mathrm{PhD}$ & Texas A\&M University & Chemistry \\
\hline Mendelsohn, Mortimer L. & $\mathrm{MD} /$ & Harvard Medical School, MA & Biophysics \\
\hline Mohrenweiser, Harvey & $\mathrm{PhD}$ & Michigan State University, E. Lansing & Biochemistry \\
\hline Nelson, David O. * & $\mathrm{PhD}$ & University of California, Berkeley & Statistics \\
\hline Prange, Christa & $\mathrm{BS}$ & St. Mary’s College, Oakland & Biology \\
\hline Rupp, Bernhard & $\mathrm{PhD}$ & University of Vienna, Austria & Chemistry \\
\hline Segelke, Brent & $\mathrm{PhD}$ & University of California, San Diego & Chemistry \\
\hline Smith, Kimothy & $\begin{array}{l}\mathrm{DVM} / \\
\mathrm{PhD}\end{array}$ & $\begin{array}{l}\text { Louisiana State Univ, A\&M } \\
\text { College }\end{array}$ & Biology \\
\hline Stubbs, Lisa J. & $\mathrm{PhD}$ & University of California, San Diego & Molecular Biology \\
\hline Thelen, Michael P. & $\mathrm{PhD}$ & Cambridge University, England & Biochemistry \\
\hline Thompson, Lawrence & $\mathrm{PhD}$ & Univ. Texas Health Center, Houston & Biophysics \\
\hline Turteltaub, Kenneth & $\mathrm{PhD}$ & Iowa State University, Ames & Toxicology \\
\hline Weinstein, Berthold W. & $\mathrm{PhD}$ & University of Illinois, Urbana & Physics \\
\hline Wyrobek, Andrew J. & $\mathrm{PhD}$ & University of Toronto, Canada & Medical Biophysics \\
\hline
\end{tabular}

* home organization is not BBRP 
Appendix I: Biology and Biotechnology Research Program Senior Staff, cont'd

\section{Post-Doctoral Staff}

\begin{tabular}{|l|l|l|}
\hline Amer, Halima & $\begin{array}{l}\text { Imperial College of Science and } \\
\text { Technology }\end{array}$ & Chemistry \\
\hline Chromy, Brett & Northwestern University, IL & Chemistry \\
\hline Dover, Nir & Hebrew University, Jerusalem, Israel & Physiology/Biotechnology \\
\hline Dugan, Lawrence & Colorado State Univ, CO & Radiobiology \\
\hline Edwards, Todd & University of Washington, Seattle, WA & Physics/Bioengineering \\
\hline Forde, Cameron & University of Toronto, Toronto, Canada & Chemistry \\
\hline Hamilton, Aaron & University of California, Riverside & Biology \\
\hline Hinz, John & University of Utah, Salt Lake City, UT & Biology/Oncology \\
\hline Huntley, Stuart & Washington State Univ, WA & Microbiology \\
\hline Kim, Ken* & University of California, Berkeley & Physics \\
\hline $\begin{array}{l}\text { Lakshmanan, } \\
\text { Nagarajan }\end{array}$ & $\begin{array}{l}\text { Concordia University, Montreal, } \\
\text { Canada }\end{array}$ & Molecular Biology \\
\hline Lau, Edmond & University of California, Santa Barbara & Chemistry \\
\hline Miller, Kristi Ann & Northwestern University, Chicago, IL & Genetic Engineering \\
\hline Pesavento, Joseph & $\begin{array}{l}\text { Baylor College of Medicine, Houston, } \\
\text { TX }\end{array}$ & Biochemistry \\
\hline Redding, Kellie & Ohio State University, OH & Molecular Biology \\
\hline Sawika, Dorota & Boston University, Boston, MA & Computational Chemistry \\
\hline Skowronek, Krzysztof & Warsaw University, Poland & Microbiology \\
\hline Sloter, Eddie Dean & West Virginia University, WV & Genetics \\
\hline Yamada, Nazumi & University of N. Carolina, Chapel, NC & Pathology \\
\hline Yin, Eric & University of Southern California & Biomedicine/Pathology \\
\hline Yoshikawa, Daniel & University of Rochester, Rochester, NY & Chemistry/Pharmacology \\
\hline Zhang, Celia & Massay University, New Zealand & Biology/Genetics \\
\hline
\end{tabular}

*home organization is not BBRP 
Appendix II: Staff Extramural Activities

Major Awards and Honors

J. Albala

REAL SCIENCE! KTEH Public Television, San Jose, CA; January 9, 2003

Mary Stuart Rogers Foundation Award, 2002

K. Dingley

IDEA Award, DOD Prostate Cancer Research Program

A. Christian

2002 R\&D100 Award for "In Situ Rolling Circle Amplification"

M. Cosman

Cover article for Chemical Research Toxicology, October, 2002

K. Kulp

American Society for Cell Biology abstract featured in press book for national meeting (additional authors: J. Montgomery, R. Latham, J. Felton and M. Bennett)

R.G. Langlois

PAT Directorate Award for development of the Autonomous Pathogen Detection System, December 2002

T. Slezak

LLNL Science \& Technology Award, 2002, "Rapid Development of Nucleic Acid Diagnostics"

\section{Invited lectures at major scientific meetings}

J. Albala

European Federation of Pharmaceutical Sciences 2002:

New Safer Medicines Faster, October 2002, Stockholm, Sweden

ICBR-Biotechnology Program Proteomics Workshop, May 2002, Gainsville, FL

Macroresults through Microarrays 3, April 2002, Boston, MA

$2^{\text {nd }}$ Annual IBC Protein Microarray Meeting, Mar 2002, San Diego, CA

LabAutomation 2002, January 2002, Palm Springs, CA

Lecturer, San Joaquin Co. Office of Education, Biotech

Consortium, Stockton, CA, 2002 
J. Albala (cont.)

P. T. Beernink

P. Chain

A. Christian

M.A. Coleman

M.E. Colvin

M. Cosman

K. Dingley
Third Annual Teller Symposium, September 2002, LLNL

Workshop Presenter, Expanding Your Horizons, University of the Pacific, Stockton, CA, 2002

Science Day Panelist, 2002

Colorado Biocalorimetry Symposium, Denver, CO

West Coast Biocalorimetry Workshop, San Francisco, CA

10th International Conference on Microbial Genomes, September 2002, Lake Arrowhead, CA

24th Chilean Microbiology Congress, December 2002, Punta de Tralca, Chile

JASON committee briefing on nanobiology

Department of Energy, Low-dose Radiation Program Workshop III.

Sixteenth Symposium of the Protein Society

"Prospects for Computational Biochemistry"

Supercomputing 2002 "Masterworks Speaker", Baltimore, MD, November 20, 2002

Gordon Conference on Mutagenesis and Carcinogenesis, Ventura, CA, March 3 - 8, 2002

American Association for Cancer Research, San

Francisco, CA April 7, 2002

Seminar: Center in Molecular Toxicology and Department of Biochemistry, School of Medicine, Vanderbilt University, Nashville TN, April 19, 2002

Seminar: Life Science Division, Oak Ridge National Laboratory, Oak Ridge, TN, April 22, 2002

Seminar: Chemistry Department, City College of CUNY, New York, NY, April 24, 2002

American Chemical Society, April 2002, Orlando, FL

Society of Toxicology, March 2002, Nashville, TN 
J. Felton

K.A. Fidelis

E. Garcia

K. Kulp

R.G. Langlois
Natl. Breast Cancer Advocates, January 2002, San Francisco, CA

Univ. Ark. Cancer Center Colon Cancer Symposium, February 2002, Little Rock, AR

Sinai Medical School Comprehensive Cancer Center, May 2002, NY, NY

NIH In service Seminar, Oct. 2002, NIH, Bethesda, MD

NIA, Seminar, Oct. 2002, Baltimore, MD

CHORI Seminar, Oct. 2002, Oakland, CA

UCLA Symposium on Toxic Subst., Nov 2002, Riverside, CA

The $31^{\text {st }}$ Conference on Applications of Mathematics, September 2002, Zakopane, Poland

Pacific Symposium on Biocomputing, January 2003, Lihue, $\mathrm{HI}$

$8^{\text {th }}$ International Symposium on Yersinia, September 4-8, 2002, Turku, FINLAND

$24^{\text {Th }}$ Annual Meeting of Chilean Association for Microbiology, December 4-6, 2002, Punta de Tralca, CHILE

Seminar: Austral University, Valdivia, CHILE, March 15, 2002

Genetics and the Courts Conference, Nov. 2002, Squaw Valley, CA

MASINT BW Symposium, April 29-May 2, 2002, Monterey, CA

EINSHAC Conference on Bioterrorism, Biological Attack and the Courts, January 17-19,2002, Livermore, CA

CJER Genetics and the Courts Conference, November 6-9, Squaw Creek, CA 
F. Marchetti

M.L. Mendelsohn

H. Mohrenweiser

B. Segelke

T. Slezak

L. Stubbs

L.H. Thompson
National Institute of Environmental Health Sciences Invited Guest Seminar Series, April 26, 2002, Research Triangle Park, NC

Speaker at BBRP Panel for LLNL 50 ${ }^{\text {th }}$ Birthday, September 19, 2002.

CBST workshop, LLNL, December 18, 2002.

Seventh International Radiopharmaceutical Dosimetry Symposium April, 2002, Nashville, TN

American Association for Cancer Research, San Francisco, CA.

Environmental Mutagen Society, Anchorage, AK

Gordon Conference, Ventura, CA

Fred Hutchinson Cancer Research Center - Symposium, Seattle, WA

University of Louisville Workshop - Pharmacogenomics and Minority Populations, Chicago, IL

NCI Workshop - "Cancer Family Registry Breast Cancer Studies" New York, NY

Automation for High Throughput Structure Determination Workshop Lawrence Berkeley National Laboratory, December 6 - 8, 2002

Microbial Forensics, November 20002, Banbury Center, Cold Spring Harbor, NY

Annual Symposium on Comparative Genomics, May 2002 University of Virginia, Charlottesville, VA

Cold Spring Harbor Laboratory Annual Conference, Mouse Molecular Genetics, August 2002, Cold Spring Harbor, NY

Gordon Conference on Molecular Cytogenetics, August 2002, Newport, RI

Thirty-third Annual Meeting of the Environmental Mutagen Society, Anchorage, Alaska, April 2002 (Symposium on Double-Strand Breaks) 
Thompson (cont.)

A. Wyrobek

\section{Editorial Boards}

J. Albala

R. Balhorn

A. Christian

M.E. Colvin
Forty-ninth Annual Meeting of the Radiation Research Society, Reno, Nevada, April 2002 (Symposium on Genes Affecting Radiosensitivity and Genome Instability)

Workshop on "Intersection of Biological and Accelerator Sciences" sponsored by the Idaho National Engineering and Environmental Laboratory (INEEL), Pocatello, ID, August 2002

National Institute of Environmental Health Sciences Workshop, invited speaker, January 2002, Reseach Triangle Park NC

Department of Energy Low Dose Radiation Effects, invited speaker, March 2002, Washington DC

Cancer Risk Assessment Workshop, invited speaker, July 2002, Washington, DC

California Tobacco Related Disease Research Program Annual Meeting, invited speaker, December 2002, Oakland, CA

Expert Reviews In Proteomics

Expert Reviews In Molecular Diagnostics

BioInsights, Inc (Protein Chip Publication)

Protein Arrays, Biochips, and Proteomics: The Next Phase of Genomic Discovery; Marcel Dekker Publisher; Ian Humphery-Smith, co-editor (in press)

Molecular Reproduction and Development

International Journal of Biophysics

Review of Scientific Instruments

Expert Review of Proteomics

Computer Physics Communications, Specialist Editor, Biophysics and Biochemistry

Journal of Computational Methods in Science and Engineering 
J.S. Felton

N. Liu

H. Mohrenweiser

T. Slezak

L.H. Thompson

A.J. Wyrobek

Societies (Major Roles)

P. T. Beernink

M.A. Coleman

J. Felton

\section{Advisory Committees}

J.S. Albala

R. Balhorn

M.E. Colvin
Mutation Research

Environmental and Molecular Mutagenesis

Journal of Biomedicine and Biotechnology (editor)

Genomics

Fundamental and Molecular Mechanisms of Mutagenesis

Briefings in Bioinformatics

Molecular and Cellular Biology

Somatic Cell and Molecular Genetics

DNA Repair

Environmental and Molecular Mutagenesis

Mutation Research
Western Biocalorimetry Society, Co-chair

Protein Society Education Working Group

Environmental Mutagen Society, Chair, Nominating

Committee
Grant Review Panel UC BioSTAR

Executive Committee, NSF Center for Biophotonics

Science and Technology, University of California, Davis

Part-time Assignee US Dept. of Energy Office of

Biological and Environmental Research

Member of Executive Committee - University of California Systemwide Biotechnology Research and Education Program

Member of External Review Committee for Oak Ridge National Laboratory Computing and Computationa 
Colvin (cont.)

M. Cosman

J. Felton

E. Garcia

R.G. Langlois

H. Mohrenweiser
Science Program (Organized by the Science and Technology Committee of the Board of Governors of U.Tenn.-Battelle)

NIH Study Section on BISTI Pre-Centers of Excellence in Biomedical Computing

Life Sciences/Information Technology (LS/IT) study section for the Discovery Grants

NIH/EPA Agricultural Health Study Advisory Board, Chair

State of California Prop 65 Cancer Advisory Board

UCTSR\&TP Executive Board

NCI Grants Subcommittee E (PO1 Oversight standing Panel)

Chair for two PO1 review

NTP/NIEHS Report on Carcinogens (Heterocyclic

Amines)- Testimony to Board of Sci. Councilors

Executive Committee, UC Davis Cancer Center

DOD, Breast Cancer Grant Rev. Committee

Grant review Study Section on Biodefense, NIAID, Department of Health and Human Services, Bethesda, MD

International Advisory Council for the Applied Ecology Research Laboratory

Cancer Epidemiology Advisory Committee, M. D. Anderson Cancer Center, Department of Epidemiology

Program in Cancer Susceptibility, Wake Forest School of Medicine, Dept of Cancer Biology

National Public Radio - "Genome Radio Project, The DNA" Files series (winner of a Peabody Award and a Robert Woods Johnson Foundation award in 2002) 
Mohrenweiser (cont.)

T. Slezak

L. Stubbs

L.H. Thompson
A.J. Wyrobek
Committee on Interagency Radiation Research and Policy
Determination (CIRRPC) Office of Science and
Technology Policy, Executive Office of the President
Executive Committee, UC Biotechnology STAR Project

Queensland, Australia

University of Washington Program in "Transgenic

mouse models of human repair gene variation"

University of Texas, San Antonio Program in

"Transgenic mouse models of human repair gene variation"

New York University Breast Cancer Program

U.S. Rice Genome Sequencing Project, Chairperson

Maize Genetics Database Steering Committee, Chairperson

National Institutes of Health, Genome Study Section

DOE Biological and Environmental Research Advisory

Committee (BERAC)

Mouse Genome Database Advisory Committee

U.C. Davis Cancer Center Internal Advisory Committee

External advisor for Fanconi Anemia Program Project, Oregon Health Sciences University, Portland, Oregon, May 2002

Member of grant application review panel for DOE's Low Dose Program, Washington, D.C., June 2002 
J.S. Albala

K.A. Fidelis

H. Mohrenweiser 2nd Annual CHI Peptalk, January 13-16, 2003, San Diego, CA

Organizing Committee member, "Fifth Critical Assessment of Protein Structure Prediction (CASP5)" meeting, December 2003, Asilomar Conference Grounds, Pacific Grove, CA

American Association Cancer Research, April 2003, Toronto, ONT, Canada

Program Committee, Epidemiology subcommittee chair 
Appendix III: Publications and other information transfer

BBRP utilizes many different methods to transfer information to the public, including those listed in the table below. Data for 2001 is included for comparison. Publication and patent information constitute the remainder of this appendix.

\begin{tabular}{|l|c|c|}
\hline Information type & CY2001 & CY2002 \\
\hline Journal Articles (peer reviewed) & 66 & 57 \\
Chapters, Reviews & 6 & 4 \\
Patents Issued & 4 & 7 \\
Patents Pending & 10 & 5 \\
Invention Disclosures & 5 & 6 \\
Income from Royalties and Licensing & Data n/a & $\$ 260,444$ \\
Presentations at Technical Meetings & 61 & 62 \\
cDNA clones made available & $\sim 1,250,000$ & $1,253,000$ \\
\hline
\end{tabular}

Citations offer a count of the number of times a publication is referenced and indicate that the publication represents ground-breaking work in the field. The following list includes the 10 manuscripts, published in the last five years with one or more authors from BBRP, that have received the most citations.

\begin{tabular}{|c|c|}
\hline Bibliographic Citation of Paper & $\begin{array}{l}\text { Number of } \\
\text { Citations }\end{array}$ \\
\hline $\begin{array}{l}\text { Kestila, M., Lenkkeri, U., Mannikko, M., Lamerdin, J., } \\
\text { McCready, P., Putaala, H., Ruotsalainen, V., Morita, T., Nissinen, } \\
\text { M., Herva, R., Kashtan, C. E., Peltonen, L., Holmberg, C., Olsen, } \\
\text { A., and Tryggvason, K. Positionally cloned gene for a novel } \\
\text { glomerular protein - nephrin - is mutated in congenital nephrotic } \\
\text { syndrome. 1, 575-582. 98. Mol. Cell. } 98 .\end{array}$ & 219 \\
\hline $\begin{array}{l}\text { Hemminki, A., Markie, D., Tomlinson, I., Avizienyte, E., Roth, } \\
\text { S., Loukola, A., Bignell, G., Warren, W., Aminoff, M., Hoglund, } \\
\text { P., Jarvinen, H., Kristo, P., Pelin, K., Ridanpaa, M., Salovaara, R., } \\
\text { Toro, T., Bodmer, W., Olschwang, S., Olsen, A. S., Stratton, M. } \\
\text { R., de la Chapelle, A., and Aaltonen, L. A. A serine/threonine } \\
\text { kinase gene defective in Peutz-Jeghers syndrome. 391, 184-187. } \\
\text { 98. Nature. } 98 .\end{array}$ & 189 \\
\hline $\begin{array}{l}\text { Shen, M. R., Jones, I., and Mohrenweiser, H. Non-conservative } \\
\text { amino acid substitution variants exist at polymorphic frequency in } \\
\text { DNA repair genes in healthy humans. 58, 604-608. 98. Cancer } \\
\text { Res. } 97 .\end{array}$ & 129 \\
\hline
\end{tabular}




\begin{tabular}{|l|l|}
\hline Bibliographic Citation of Paper, cont'd & $\begin{array}{l}\text { Number of } \\
\text { Citations }\end{array}$ \\
\hline $\begin{array}{l}\text { Liu, N., Lamerdin, J. E., Tebbs, R. S., Schild, D., Tucker, J. D., } \\
\text { Shen, M. R., Brookman, K. W., Siciliano, M. J., Walter, C. A., } \\
\text { Fan, W., Narayana, L. S., Zhou, Z., Adamson, A. W., Sorensen, } \\
\text { K. J., Chen, D. J., Jones, N. J., and Thompson, L. H. XRCC2 and } \\
\text { XRCC3, new human Rad51-family members, promote } \\
\text { chromosome stability and protect against DNA crosslinks and } \\
\text { other damages. 1, 783-793. 98. Mol. Cell. 98. }\end{array}$ & \\
\hline $\begin{array}{l}\text { Lal, A., Lash, A. E., Altschul, S. F., Velculescu, V., Zhang, L., } \\
\text { McLendon, R. E., Marra, M. A., Prange, C., Morin, P. J., Polyak, } \\
\text { K., Papadopoulos, N., Vogelstein, B., Kinzler, K. W., Strausberg, } \\
\text { R. L., and Riggins, G. J. A public database for gene expression in } \\
\text { human cancers. 59, 5403-5407. 2000. Cancer Res. 99. }\end{array}$ & \\
\hline $\begin{array}{l}\text { Johnson, R. D., Liu, N., and Jasin, M. Mammalian XRCC2 } \\
\text { promotes the repair of DNA double-strand breaks by homologous } \\
\text { recombination. 401, 397-399. 99. Nature. 99. }\end{array}$ & 91 \\
\hline $\begin{array}{l}\text { Porcelli, S. A., Segelke, B. W., Sugita, M., Wilson, I. A., and } \\
\text { Brenner, M. B. The CD1 family of lipid antigen-presenting } \\
\text { molecules. 19(8), 362-368. 98. Immunology Today. 98. }\end{array}$ & 73 \\
\hline $\begin{array}{l}\text { Thompson, L. H. and Schild, D. The contribution of homologous } \\
\text { recombination in preserving genome integrity in mammalian } \\
\text { cells. 81, 87-105. 99. Biochime. 98. }\end{array}$ & 72 \\
\hline $\begin{array}{l}\text { Thelen, M., Venclovas, C., and Fidelis, K. A sliding clamp model } \\
\text { for the Rec1 family of cell cycle checkpoint proteins. 96, 769- } \\
\text { 770. 99. Cell. 98. }\end{array}$ & 64 \\
\hline $\begin{array}{l}\text { Dosanjh, M. K., Collins, D. W., Fan, W., Lennon, G. G., Albala, } \\
\text { J. S., Shen, Z., and Schild, D. Isolation and characterization of } \\
\text { RAD51C, a new human member of the RAD51 family related } \\
\text { genes, including two-hybrid interactions. 26(5), 1179-1184. 98. } \\
\text { Nucleic Acids Res. 97. }\end{array}$ & \\
\hline
\end{tabular}




\section{Manuscripts and Book Chapters Published in 2002:}

Agron, P. G., Macht, M., Radnedge, L., Skowronski, E. W., Miller, W., and Andersen, G. L. (2002). Use of subtractive hybridization for comprehensive surveys of prokaryotic genome differences. FEMS Microbiol. Lett., 211(2), 175-182.

Agron, P. G., Sobecky, P., and Andersen, G. L. (2002). Establishment of uncharacterized plasmids in Escherichia coli by in vitro transportation. FEMS Microbiol. Lett., 217(2), 249-254.

Albala, J. S. (2002). Chips to hits 2001: An array of parallel technologies converge. Expert Rev. Mol. Diagn., 2(1), 13-15.

Balu, N., Gamcsik, M. P., Colvin, M. E., Colvin, O. M., Dolan, M. E., and Ludeman, S. M. (2002). Modified guanines Representing O6-alkylation by the cyclophosphamide metabolites acrolein and chloroacetaldehyde: Synthesis, Stability, and ab initio studies. Chem. Res. Toxicol., 15(3), 380-387.

Bennett, L. M. and Davis, B. J. (2002). Identification of mammary carcinogens in rodent bioassays. Environ. Mol. Mutagen., 39(2-3), 150-157.

Branscomb, E. and Predki, P. (2002). On the high value of low standards. J. Bacteriol., 184(3), 6406-6409.

Chiarappa-Zucca, M. L., Dingley, K. H., Roberts, M. L., Veksko, C. A., and Love, A. H. (2002). Sample preparation for quantitation of tritium by accelerator mass spectrometry. Anal. Chem., 74(24), 6285-6290.

Chittenden, L., Lu, X., Nestor, L. A., Cacheiro, N. L. A., Cain, K. T., Generoso, W., Bryda, E. C., and Stubbs, L. (2002). A new mouse model for autosomal recessive polycystic kidney disease. Genomics, 79(4), 499-504.

Christian, A. T. (2002). A cytogenetic footprint for mammary carcinomas induced by PhIP in rats. Toxicol., 181-182, 95-97.

Christian, A. T., Pattee, M. S., and Marchetti, F. (2002). Meiotic chromosomes as templates for microdissection. Chrom. Res., 10(1), 45-48.

Christian, A. T., Snyderwine, E. G., and Tucker, J. D. (2002). Comparative genomic hybridization analysis of PhIP-induced mammary carcinomas in rats reveals a cytogenetic signature. Mutat. Res., 113.

Corzett, M., Mazrimas, J., and Balhorn, R. (2002). Protamine 1: Protamine 2 stoichiometry in the sperm of eutherian mammals. Mol. Reprod. Dev., 61, 519-527.

Cosman, M., Lighstone, F. C., Krishnan, V. V., Zeller, L., Prieto, M. C., Roe, D. C., and Balhorn, R. (2002). Identification of novel small molecules that bind to two different sites on the surface of tetanus toxin C fragment. Chem. Res. Toxicol., 15(10), 1218-1228. 
Eskenazi, B., Wyrobek, A. J., Sloter, E., Kidd, S. A., Moore, L., Young, S. S., and Moore, D. (2002). The association of age and semen quality in healthy men. Human Reprod.

Felton, J. S., Knize, M. G., Salmon, C. P., Malfatti, M. A., and Kulp, K. (2002). Human exposure to heterocyclic amine food mutagens/carcinogens: Relevance to breast cancer. Environ. Mol. Mutagen., 39, 112-118.

Forde, C., Gonzales, A., Smessaert, J., Murphy, G., Shields, S., Fitch, J. P., and McCutchen-Maloney, S. L. (2002). A rapid method to capture and screen transcription factors by SELDI mass spectrometry. Biochem. Biophys. Res. Commun., 290, 1328-1335.

Gardner, S. and Agrawl, A. A. (2002). Induced host defense as a strategy to delay the evolution of resistance in parasites. Evolutionary Ecol. Res., 4, 1131-1151.

Gardner, S. N. (2002). Cell-cycle phase-specific chemotherapy: Computational methods for guiding treatment. Cell Cycle, 1(6), 369-374.

Gardner, S. N. (2002). Modeling multi-drug chemotherapy: Tailoring treatment to individuals. J. Theor. Bio., 214, 181-207.

Gardner, S. N. and Thomas, M. B. (2002). Costs and benefits of fighting infection in locusts. Evolution. Ecology Res., 4(1), 109-131.

Gardner, S. N. and Tucker, J. D. (2002). The cellular lethality of radiation-induced chromosome translocations in human lymphocytes. Rad. Res., 157(5), 539-552.

Hadi, M. Z., Ginalski, K., Nguyen, L. H., and Wilson, D. M. III. (2002). Determinants in nuclease specificity of Ape1 and Ape2, human homologues of Escherichia coli exonuclease III. J. Mol. Bio., 316(3), 853-866.

King, L. M., Ma, J., Srettabunjong, S., Li, L., Graves, J., Spiecker, M., Liao, J. K., Mohrenweiser, H. W., and Zeldin, D. C. (2002). Cloning of the CYP2J2 gene identification of functional polymorphisms. Mol. Pharm., 61(4), 840-852.

Knize, M. G., Kulp, K., Salmon, C. P., Keating, G. A., and Felton, J. S. (2002). Factors affecting human heterocyclic amine intake and the metabolism of PhIP. Mutat. Res., 506507(153-162).

Krupka, H. I., Segelke, B. W., Ulrich, R. G., Ringhofer, S., Knapp, M., and Rupp, B. (2002). Structural basis for abrogated binding between staphylococcal enterotoxin A superantigen vaccine and MHC-II. Protein Sci., 11, 642-651.

Kumaresan, K. R., Hwang, M., Thelen, M. P., and Lambert, M. W. (2002). Contribution of XPF functional domains to the 5' and 3 ' incisions produced at the site of a psoralen interstrand cross-link. Biochem., 41, 890-896. 
Lee, B., Nguyen, L., Barsky, D., Fernandes, M., and Wilson, D. M. (2002). Molecular interactions of human Exo1 with DNA. Nucleic Acids Res., 30(4), 942-949.

Leininger, M. L., Nielsen, I. M. B., Colvin, M. E., and Janssen, C. L. (2002). Accurate Structures and Binding Energies for Stacked Uracil Dimers. J. Phys. Chem. A., 106, 3850-3854.

Liu, N. (2002). XRCC2 is required for the formation of Rad51 foci induced by ionizing radiation and DNA cross-linking agent mitomycin C. J. Biomed. Biotech., 2(2), 106-113.

Liu, N., Schild, D., Thelen, M. P., and Thompson, L. H. (2002). Involvement of Rad51C in two distinct protein complexes of Rad51 paralogs in human cells. Nucleic Acids Res., 30(4), 1009-1015.

Love, A. H., Hunt, J. R., Roberts, M. L., Southon, J. R., Chiarappa-Zucca, M. L., and Dingley, K. H. (2002). Use of tritium accelerator mass spectrometry for tree ring analysis. Environ. Sci. Tech., 36(13), 2848-2452.

Miano, J. M., Kitchen, C. M., Maltby, K. M., Kelly, L. A., Weiler, H., Krahe, R., Ashworth, L. K., and Garcia, E. (2002). Expression of human smooth muscle calponin in transgenic mice revealed with a bacterial artificial chromosome. Am. J. Phys., 282, 17931803.

Miller, K. A., Yoshikawa, D. M., McConnell, I. R., Clark, R., Schild, D., and Albala, J. S. (2002). RAD51C interacts with RAD51B and is central to a larger protein complex in vivo exclusive of RAD51. J. Biol. Chem., 277(10), 8406-8411.

Mohrenweiser, H. W., Xi, T., Vazquez-Matias, J., and Jones, I. M. (2002). Identification of 137 amino acid substitution variants in 37 DNA repair genes in humans. Cancer Epidemiol. Biomark. Prev., 11, 1054-1064.

Motin, V. L., Georgescu, A. M., Elliott, J. M., Hu, P., Worsham, P. L., Ott, L. L., Slezak, T. R., Sokhansanj, B. A., Regala, W. M., Brubaker, R. R., and Garcia, E. (2002). Genetic variability of Yersinia pestis isolates as predicted by PCR-based IS100 genotyping and analysis of the structural gene encoding Glycerol-3-phosphate dehydrogenase (glpD). $J$. Bacteriology, 184(4), 1019-1027.

Nguyen, D. H., Fink, W. H., Colvin, M. E., Yeh, Y., and Fenney, E. (2002). Roles of intermolecular interactions to the mechanism of action of winter flounder antifreeze protein. Biophysical J., 82(6), 2892-2905.

Platner, J., Bennett, L. M., Millikan, R., Barker, M., and Visco, F. (2002). The partnership between breast cancer advocates and scientists. Environ. Mol. Mutagen., 39, 102-107.

Price, S. J., Chittenden, L. R., Flaherty, L., O’Dell, B., Guay-Woodford, L., Stubbs, L., and Bryda, E. C. (2002). Characterization of the region containing the jcpk PKD gene on mouse chromosome 10. Cytogenet. Gen. Res., 98(1), 61-66. 
Qiao, Y., Spitz, M. R., Sheng, H., Guo, Z., Shete, S., Hadeyati, M., Grossman, L., Kraemer, K. H., Mohrenweiser, H. W., and Wei, Q. (2002). Modulation of repair of ultraviolet damage in the host-cell reactivation assay by polymorphic XPC and XPD/ERCC2 genotypes. Carcinogenesis, 23, 295-299.

Radnedge, L., Agron, P. A., Worsham, P. L., and Andersen, G. L. (2002). Genome plasticity in Yersinia pestis. Microbiol., 148(6), 1687-1698.

Radosevich, J. L., Wilson, W. J., Shinn, J. H., Desantis, T. Z., and Andersen, G. L. (2002). Development of a high-volume aerosol collection system for the identification of air-borne micro-organisms. Lett. App. Microbiol., 34(3), 162-167.

Rubes, J., Vozdova, M., Robbins, W. A., Rezacova, O., Perrault, S. D., and Wyrobek, A. J. (2002). Stable Variants of Sperm Aneuploidy among Healthy Men Show Associations between Germinal and Somatic Aneuploidy. Am. J. Human Genet., 70(6), 1507-1519.

Sasaki, J. C., Fellers, R. S., and Colvin, M. E. (2002). Metabolic oxidation of carcinogenic arylamines by P-450 monooxygenases: Theorectical support for the one electron transfer mechanism. Mutat. Res., 506-507, 79-89.

Sibley, A., Cosman, M., and Krishnan, V. V. (2002). Averaged chemical shifts to estimate protein secondary structure content from NMR spectra without resonance assignments. Biophys. J., 84, 1223-1227.

Sigurdsson, S., Van Komen, S., Bussen, W., Schild, D., Albala, J., and Sung, P. (2002). Mediator function of the human Rad51B-Rad51C complex in Rad51/RPA-catalyzed DNA strand exchange. J. Genes Dev., 15, 3308-3318.

Sokhansanj, B. A., Rodrigue, G. R., Fitch, J. P., and Wilson, D. M. (2002). A quantitative model of human DNA base excision repair: I. Mechanistic insights. Nucleic Acids Res., 30(8), 1817-1825.

Sorensen, K. J., Attix, C. M., Christian, A. T., Wyrobek, A. J., and Tucker, J. D. (2002). Adaptive response induction and variation in human lymphoblastoid cell lines.

Mutat.Res., 519(1-2), 15-24.

Thomas, C. B., Nelson, D. O., Pleshanov, P., and Jones, I. M. (2002). Induction and decline of HPRT mutants and deletions following a low dose radiation exposure at Chernobyl. Mutat. Res., 499, 177-187.

Tomascik-Cheeseman, L. M., Marchetti, F., Shamanski, F. L., Pederson, R., Nath, J., and Wyrobek, A. J. (2002). CENP-B is not critical for meiotic chromosome segregation in male mice. Mutat. Res., 513(1-2), 197-203.

Tran, N. L., Salmon, C. P., Knize, M. G., and Colvin, M. E. (2002). Experiments and simulation studies of heat flow and heterocyclic amine mutagen/carcinogen formation in pan-fried meat patties. Food Chem. Toxicol., 40(5), 673-684. 
Tsvetkova, N. M., Phillips, B. L., Krishnan, V. V., Feeney, W. H., Fink, J. H., Crowe, S. H., Risbud, S. H., Tablin, F., and Yeh, Y. (2002). Dynamics of antifreeze glycoproteins in the presence of ice. Biophys. J., 82(1), 464-473.

Tucker, J. D. (2002). Sensitivity, specificity, and persistence of chromosome translocations for radiation biodosimetry. Military Med., 167(2), 8-9.

Venclovas, C., Colvin, M. E., and Thelen, M. P. (2002). Molecular modeling-based analysis of interaction in the RFC-dependent clamp-loading process. Protein Sci., 11(10), 2403-2416.

Wheelock, C. E., Colvin, M. E., Uemura, I., Olmstead, M. M., Sanborn, J. R., Nakagawa, Y., and Hammock, B. D. (2002). Use of ab initio calculations to predict the biological potency of carboxylesterase inhibitors. J. Med. Chem., 45(25), 5576-5593.

Wiese, C., Collins, D. W., Albala, J. S., Thompson, L. H., Kronenberg, A., and Schild, D. (2002). Interactions involving the Rad51 paralogs Rad51C and XRCC3 in human cells. Nucleic Acids Res., 30(4), 1001-1008.

Wilson, K. H., Wilson, W. J., Radosevich, J. L., DeSantis, T. Z., Viswanathan, V. S., Kuczmarski, T. A., and Andersen, G. L. (2002). High-density microarray of smallsubunit ribosomal DNA probes. App. Environ. Microbiol., 68(5).

Wilson, W. J., Strout, C., DeSantis, T. Z., Stilwell, J. L., Carrano, A. V., and Andersen, G. L. (2002). Sequence-specific identification of 18 pathogenic microorganism using microarray technology. Mol. Cell. Probes., 16(2), 119-127.

\section{Book Chapters (2002):}

Colvin, M. E. and Quong, J. N. (2002). DNA-alkylating events associated nitrogen mustard based anticancer drugs and metabolic byproduct acrolein. In: Advances in DNA Sequences Specific Agents., Elsevier, N.Y., ed., Jones, G.B., 4, 29-46.

Dingley, K. H.; Ubick, E. A.; Vogel, J. S., and Haack, K. W. (2003). DNA isolation and sample preparation for quantitation of adduct levels by Accelerator Mass Spectrometry. In: Method in Molecular Biology., Protocols in Molecular Toxicology, Humana, Totowa, NJ., eds., Keohavong, P. and Grant, S.G. (in press)

Mohrenweiser, H. W. (2002). Individual susceptibility to exposures: A role for genetic variation in DNA repair genes. In: Technology-Driven Biomarker Development Application in Environmentally-Associated Disease., eds., Wilson, S.H. and Suk, W.A., 63-82.

Vazquez-Matias, J. and Mohrenweiser, H. W. (2002). Lactate dehydrogenase: LDHA, LDHB and LDHC . In: Wiley Encyclopedia of Molecular Medicine., 5, 1891-1894. 


\section{Manuscripts "In Press" in December 2002:}

Forde, C. E. and McCutchen-Maloney, S. L. Characterization of transcription factors by mass spectrometry and the role of SELDI-MS. Mass Spec. Rev.

Gardner, S. N.; Kuczmarski, T. A.; Vitalis. E.A., and Slezak, T. R. Limitations of TaqMan PCR for detecting divergent viral pathogens: Examples using Hepatitises A, B, C, E, and HIV viruses and alternative detection methods. J. Clinical Microbio.

Lamberton, J. and Christian, A. T. Varying the nucleic acid compostition of siRNA molecules dramatically varies the duration and degree of gene silencing. Mol. Biotech.

Perreault, S. D.; Aitken, R. J.; Gordon Baker, H. W.; Everson, D. P.; Huszar, G.; Irvine, D. S.; Morris, I. D.; Morris, R. A.; Robbins, W. A.; Sakkas, D.; Spano, M., and Wyrobek, A. J. Integrating new tests of sperm genetic integrity into semen analysis: Breakout group discussion. Male Mediated Develop. Toxicity.

Radnedge, L.; Agron, P. G.; Hill, K. K.; Jackson, P. J.; Ticknor, L. O.; Keim, P., and Andersen, G. L. Genome differences that distinguish $B$. anthracis from closely related Bacillus cereus and Bacillus thuringiensis. App. Env. Microbio.

Schild, L. J.; Brookman, K. W.; Thompson, L. H., and Wilson, D. H. Effects of Ape1 overexpression on cellular resistance to DNA-damaging and anti-cancer agents. Somatic Cell Mol. Genet.

Tucker, J. D.; Moore, D. H.; Ramsey, M. J.; Kato, P.; Langlois, R. G.; Burroughs, B.; Long, L., and Garr, V. F. Multi-endpoint biological monitoring of phosphine workers. Mut. Res. 
Appendix IV: Patents and Invention Disclosures

\begin{tabular}{|c|c|c|c|c|}
\hline \multicolumn{3}{|l|}{ Patents Issued - 2002} & US Patent \# & Issue Date \\
\hline S. McCutchen-Maloney & \multicolumn{2}{|c|}{$\begin{array}{l}\text { Mismatch Detection using a } \\
\text { Thermophilic MutS Protein }\end{array}$} & 6340566 & $1 / 22 / 02$ \\
\hline S. McCutchen-Maloney & \multicolumn{2}{|c|}{$\begin{array}{l}\text { Design and Development of Four } \\
\text { Chimeric Proteins to Detect and } \\
\text { Quantitate DNA Damage and } \\
\text { DNA Mismatches which Can } \\
\text { Lead to Mutation and Cancer }\end{array}$} & 6365355 & $4 / 2 / 02$ \\
\hline $\begin{array}{l}\text { S. Visuri, L. Da Silva, P. } \\
\text { Celliers, R. London, W. } \\
\text { Benett, K. Broughton } \\
\end{array}$ & \multicolumn{2}{|c|}{$\begin{array}{l}\text { Opto-Acoustic Recanilization } \\
\text { Delivery System }\end{array}$} & 6368318 & $4 / 9 / 02$ \\
\hline $\begin{array}{l}\text { J.C. Davidson, J.W. } \\
\text { Balch }\end{array}$ & \multicolumn{2}{|c|}{$\begin{array}{l}\text { Vacuum Pull Down Method for } \\
\text { Enhanced Bonding Arbitrary } \\
\text { Substrates, Sizes and Shapes } \\
\end{array}$} & 6372328 & $4 / 16 / 02$ \\
\hline R.L. Balhorn, C.H. Barry & \multicolumn{2}{|c|}{$\begin{array}{l}\text { Method of Microsphere } \\
\text { Attachment to DNA }\end{array}$} & 6420112 & $7 / 16 / 02$ \\
\hline $\begin{array}{l}\text { S. Visuri, L. Da Silva, P. } \\
\text { Celliers, R. London, D.J. } \\
\text { Maitland }\end{array}$ & \multicolumn{2}{|c|}{$\begin{array}{l}\text { Opto-Acoustic Recanilization } \\
\text { (OAR) Laser }\end{array}$} & 6428531 & $8 / 6 / 02$ \\
\hline $\begin{array}{l}\text { A.T. Christian, M.A. } \\
\text { Coleman, J.D. Tucker }\end{array}$ & \multicolumn{2}{|c|}{$\begin{array}{l}\text { Tissue-specific and Chromosome } \\
\text { Region-specific Isolation of Gene } \\
\text { Expression Libraries }\end{array}$} & 6432650 & $8 / 13 / 02$ \\
\hline \multicolumn{5}{|l|}{ Patents Pending - 2002} \\
\hline \multicolumn{2}{|c|}{ R. Madabhushi, S.A. Gammon } & \multicolumn{2}{|c|}{$\begin{array}{l}\text { Polyacrylamide Medium for the } \\
\text { Electrophoretic Separation of } \\
\text { Biomolecules }\end{array}$} & 10760 \\
\hline \multicolumn{2}{|c|}{$\begin{array}{l}\text { B.W. Colston, Jr., S.B. Brown, } \\
\text { S. Nasarabadi, P. Belgrader, F. } \\
\text { Milanovich }\end{array}$} & \multicolumn{2}{|c|}{$\begin{array}{l}\text { Automated Nucleic Acid Assay } \\
\text { Sample Preparation and Detection }\end{array}$} & 10778 \\
\hline \multicolumn{2}{|c|}{$\begin{array}{l}\text { H.I. Krupka, B.W. Segelke, B. } \\
\text { Rupp }\end{array}$} & \multicolumn{2}{|c|}{ Protein Crystallography PreScreen } & 10922 \\
\hline \multicolumn{2}{|c|}{$\begin{array}{l}\text { P.G. Agron, G.L. Andersen, R.L. } \\
\text { Walker }\end{array}$} & \multicolumn{2}{|c|}{$\begin{array}{l}\text { Method for the Detection of } \\
\text { Salmonella Eterica Serovar } \\
\text { Enteritidis that is Highly Specific }\end{array}$} & 10943 \\
\hline \multicolumn{2}{|c|}{$\begin{array}{l}\text { B.W. Segelke, H.I. Krupka, B. } \\
\text { Rupp }\end{array}$} & \multicolumn{2}{|c|}{$\begin{array}{l}\text { Automated Macromolecular } \\
\text { Crystallization Screening with } \\
\text { Random Sampling }\end{array}$} & 10986 \\
\hline
\end{tabular}


Appendix IV: Patents and Invention Disclosures, cont'd

\begin{tabular}{l|l|c}
\hline $\begin{array}{l}\text { Invention Disclosures - 2002 } \\
\text { Inventors }\end{array}$ & \multicolumn{2}{c}{ Title } \\
\hline A.T. Christian, B. Segelke & $\begin{array}{l}\text { Automated Macromolecular Crystal } \\
\text { Detection from Light Microscopy } \\
\text { Images }\end{array}$ & 10961 \\
\hline $\begin{array}{l}\text { A.T. Christian, B. Segelke, B. } \\
\text { Rupp }\end{array}$ & $\begin{array}{l}\text { Augmented Automated } \\
\text { Macromolecular Crystal Detection } \\
\text { from Light Microscopy Images }\end{array}$ & 11013 \\
\hline $\begin{array}{l}\text { R.G. Langlois, F.M. } \\
\text { Milanovich, B.W. Colston, } \\
\text { Jr., S.B. Brown, D.A. } \\
\text { Masquelier, R.P. Mariella }\end{array}$ & $\begin{array}{l}\text { System for Autonomous Monitoring } \\
\text { of Bioagents }\end{array}$ & 11052 \\
\hline $\begin{array}{l}\text { A.T. Christian, J.S. } \\
\text { Lamberton }\end{array}$ & $\begin{array}{l}\text { Gene Silencing Using DNA:RNA- } \\
\text { Hybrid Short, Interfering Molecules }\end{array}$ & 11065 \\
\hline $\begin{array}{l}\text { B.W. Segelke, A. Newman, T. } \\
\text { Lekin }\end{array}$ & $\begin{array}{l}\text { Database for Data Tracking and } \\
\text { Analysis of Automated Random } \\
\text { Crystallization Screening }\end{array}$ & 11078 \\
\hline $\begin{array}{l}\text { A.J. Wyrobek, F.S. Hill, F.O. } \\
\text { Marchetti }\end{array}$ & $\begin{array}{l}\text { Multilabeling Mouse FISH Assay } \\
\text { for Detecting Structural and } \\
\text { Numerical Chromosomal } \\
\text { Abnormalities }\end{array}$ & 11097 \\
\hline
\end{tabular}


Appendix V: Funding information (listed by sponsoring agency)

Work For Others:

Sponsor Support (K\$) Principal Investigator Objective

\begin{tabular}{|c|c|c|c|}
\hline ARMY & 94.8 & L. Thompson & $\begin{array}{l}\text { Determine the } \\
\text { mechanisms of repair for } \\
\text { radiation-induced DNA } \\
\text { damage related to cancer } \\
\text { treatment }\end{array}$ \\
\hline $\begin{array}{l}\text { Battelle Memorial } \\
\text { Institute }\end{array}$ & 212.3 & J. Tucker & $\begin{array}{l}\text { Quantify chromosome } \\
\text { damage in airline flight } \\
\text { crews by using whole } \\
\text { chromosome painting } \\
\text { (FISH) }\end{array}$ \\
\hline DARPA & 308.0 & A. Christian & $\begin{array}{l}\text { Develop a portable device } \\
\text { to synthesize long chain } \\
\text { nucleic acids }\end{array}$ \\
\hline DTRA & 253.0 & J. Tucker & $\begin{array}{l}\text { Produce a working mobile } \\
\text { radiobiological dosimetry } \\
\text { system for field } \\
\text { deployment }\end{array}$ \\
\hline HHS/CDCP & 268.6 & K. Fidelis & $\begin{array}{l}\text { To support the continuing } \\
\text { operation of the Critical } \\
\text { Assessment of Protein } \\
\text { Structure Prediction } \\
\text { (CASP) process and to } \\
\text { expand its infrastructure, } \\
\text { including an increased } \\
\text { capacity for assessing } \\
\text { predictions, further } \\
\text { development and } \\
\text { refinement of the } \\
\text { evaluation }\end{array}$ \\
\hline HHS/CNRR & $1,257.4$ & K. Turteltaub & $\begin{array}{l}\text { Develop and demonstrate } \\
\text { biomedical applications of } \\
\text { AMS and serve as a } \\
\text { resource for NIH funded } \\
\text { investigators requiring } \\
\text { AMS for their work }\end{array}$ \\
\hline $\mathrm{HHS} / \mathrm{NCI}$ & 56.3 & I. Jones & $\begin{array}{l}\text { Measure the level of DNA } \\
\text { damage using an assay } \\
\text { developed in the BBR } \\
\text { Program }\end{array}$ \\
\hline
\end{tabular}




\begin{tabular}{|c|c|c|c|}
\hline HHS/NCI & 293.7 & J. Albala & $\begin{array}{l}\text { Elucidate the relationship } \\
\text { of a newly identified } \\
\text { human gene, RAD51B, to } \\
\text { breast cancer-related } \\
\text { genes, and therefore, to } \\
\text { cancer }\end{array}$ \\
\hline HHS/NCI & $2,419.1$ & J. Felton & $\begin{array}{l}\text { Determine whether } \\
\text { heterocyclic amine } \\
\text { mutagens/carcinogens } \\
\text { contribute to human } \\
\text { cancer incidence }\end{array}$ \\
\hline HHS/NCI & 245.0 & K. Kulp & $\begin{array}{l}\text { Develop an exposure } \\
\text { assessment method that } \\
\text { will predict the effect of } \\
\text { digestion parameters, } \\
\text { intestinal transport and } \\
\text { diet upon the low dose } \\
\text { exposure to commonly } \\
\text { ingested food carcinogens }\end{array}$ \\
\hline HHS/NCI & 364.7 & L. Thompson & $\begin{array}{l}\text { Understand the molecular } \\
\text { regulatory processes cells } \\
\text { use to minimize genetic } \\
\text { damage and genetic } \\
\text { instability associated with } \\
\text { reactive oxygen species } \\
\text { arising from endogenous } \\
\text { processes or ionizing } \\
\text { radiation }\end{array}$ \\
\hline HHS/NCI & 245.9 & L. Thompson & $\begin{array}{l}\text { Understand the } \\
\text { biochemistry of a } \\
\text { mammalian DNA protein, } \\
\text { ERCC2, that serves } \\
\text { multiple roles in DNA } \\
\text { metabolism by comparing } \\
\text { the characteristics of } \\
\text { hamster cells with defects } \\
\text { in this gene with } \\
\text { molecular changes in } \\
\text { biomedical activities of } \\
\text { the proteins }\end{array}$ \\
\hline HHS/NCI & 322.8 & N. Liu & $\begin{array}{l}\text { Understand the role of } \\
\text { XRCC2 in DNA repair, } \\
\text { specifically in } \\
\text { homologous recombina- } \\
\text { tional repair pathways }\end{array}$ \\
\hline
\end{tabular}




\begin{tabular}{|c|c|c|c|}
\hline HHS/NIEHS & 50.0 & A. Wyrobek & $\begin{array}{l}\text { Develop a proposal for } \\
\text { sustainable training of } \\
\text { personnel in conduct of all } \\
\text { aspects of the mouse } \\
\text { epididymal sperm } \\
\text { aneuploidy (m-ESA) } \\
\text { assay }\end{array}$ \\
\hline HHS/NIEHS & 321.8 & H. Mohrenweiser & $\begin{array}{l}\text { Resequence exons of } 20 \\
\text { genes in } 50 \text { individuals as } \\
\text { necessary to identify DNA } \\
\text { sequence variations }\end{array}$ \\
\hline $\begin{array}{l}\text { Lawrence Berkeley } \\
\text { National Laboratory }\end{array}$ & 132.7 & L. Thompson & $\begin{array}{l}\text { Determine the molecular } \\
\text { structures of human DNA } \\
\text { repair proteins that } \\
\text { participate in homologous } \\
\text { recombination }\end{array}$ \\
\hline $\begin{array}{l}\text { Los Alamos National } \\
\text { Lab }\end{array}$ & 796.7 & B. Rupp & $\begin{array}{l}\text { Carry out large scale } \\
\text { crystallizations of proteins } \\
\text { from Tuberculosis }\end{array}$ \\
\hline OFA & 100.0 & A. Christian & \\
\hline OFA & $1,264.1$ & P. Chain & \\
\hline Phylos & 263.0 & J. Albala & $\begin{array}{l}\text { Generate target protein } \\
\text { library microarrays }\end{array}$ \\
\hline RocheCRADA & 122.5 & P. Beernick & $\begin{array}{l}\text { Develop new applications } \\
\text { of cell-free protein } \\
\text { production }\end{array}$ \\
\hline Sloan Kettering & 112.7 & H. Mohrenweiser & $\begin{array}{l}\text { Identify genetic variants } \\
\text { existing in the human } \\
\text { population in the genes of } \\
\text { the nucleotide excision } \\
\text { repair pathway that may } \\
\text { be important in } \\
\text { determining melanoma } \\
\text { risks }\end{array}$ \\
\hline UC Berkeley & 127.4 & A. Wyrobek & $\begin{array}{l}\text { Investigate the } \\
\text { relationship between } \\
\text { aneuploidy sperm and } \\
\text { aneuploidy at birth caused } \\
\text { by parental age, diet, and } \\
\text { smoking }\end{array}$ \\
\hline
\end{tabular}




\begin{tabular}{|l|l|l|l|}
\hline UC Berkeley & 135.7 & K. Turteltaub & $\begin{array}{l}\text { Address the effects of } \\
\text { chemical dose on the } \\
\text { absorption and the } \\
\text { associated DNA and } \\
\text { protein adduct levels for } \\
\text { exposure to benzene and } \\
\text { trichlorethylene, } \\
\text { carcinogens found at } \\
\text { superfund waste sites and } \\
\text { common to the urban } \\
\text { environment }\end{array}$ \\
\hline $\begin{array}{l}\text { UC Breast Cancer } \\
\text { Research }\end{array}$ & 162.0 & K. Kulp & $\begin{array}{l}\text { Evaluation of essiac tea to } \\
\text { prevent mammary tumors } \\
\text { and improve our } \\
\text { understanding of the } \\
\text { impact of a } \\
\text { complementary and } \\
\text { alternative therapy }\end{array}$ \\
\hline UC/Biostar & 32.4 & P. Beernick & $\begin{array}{l}\text { Develop new applications } \\
\text { of cell-free protein } \\
\text { production }\end{array}$ \\
\hline University of Texas & 14.9 & H. Mohrenweiser & $\begin{array}{l}\text { Identify genetic variants } \\
\text { existing in the human } \\
\text { population at the DNA } \\
\text { repair gene } M U T Y \text { that } \\
\text { may be important in } \\
\text { determining cancer risk }\end{array}$ \\
\hline
\end{tabular}


DOE (Office of Biological \& Environmental Research):

Support (K\$) Principal Investigator

\begin{tabular}{|c|c|c|}
\hline 166.0 & M. Colvin & $\begin{array}{l}\text { Funds } 25 \% \text { of PI for } \\
\text { assignment to OBER to } \\
\text { assist with new programs } \\
\text { in computational biology }\end{array}$ \\
\hline 198.0 & G. Andersen & $\begin{array}{l}\text { Understand protein } \\
\text { function by understanding } \\
\text { which proteins in the } \\
\text { microbial cell specifically } \\
\text { bind to one another }\end{array}$ \\
\hline $5,000.0$ & JGI & $\begin{array}{l}\text { Poplar - DNA Sequencing } \\
\text { at the JGI/PSF }\end{array}$ \\
\hline $1,075.0$ & L. Thompson & $\begin{array}{l}\text { Understand the relative } \\
\text { contributions of the } \\
\text { individual DNA-damage } \\
\text { response pathways to the } \\
\text { recovery of mammalian } \\
\text { cells from exposure to } \\
\text { ionizing radiation (IR) in } \\
\text { the range of } 0-1 \mathrm{~Gy}\end{array}$ \\
\hline 173.0 & M. Coleman & $\begin{array}{l}\text { Build a computer-based } \\
\text { gene-network model of } \\
\text { pathways involved in } \\
\text { cellular IR-response, } \\
\text { understand the genomic } \\
\text { regulation of radiation } \\
\text { effects on transcription, } \\
\text { identify susceptibility } \\
\text { factors, and predict new } \\
\text { genes that may be } \\
\text { associated with low-dose } \\
\text { IR }\end{array}$ \\
\hline 698.0 & A. Wyrobek & $\begin{array}{l}\text { Provide mechanistic and } \\
\text { molecular knowledge of } \\
\text { the cellular response to } \\
\text { low dose IR to help } \\
\text { reduce the uncertainty in } \\
\text { assessing health risks at } \\
\text { low-dose levels, and } \\
\text { identify candidate genes } \\
\text { responsible for differential } \\
\text { susceptibility to low-dose } \\
\text { IR exposure }\end{array}$ \\
\hline
\end{tabular}




\begin{tabular}{|c|c|c|}
\hline $4,845.0$ & JGI & $\begin{array}{l}\text { Make significant } \\
\text { contribution to the } \\
\text { international Human } \\
\text { Genome Project }\end{array}$ \\
\hline $1,353.0$ & C. Prange & $\begin{array}{l}\text { Work in conjunction with } \\
\text { various external groups } \\
\text { such as the National } \\
\text { Institutes of Health } \\
\text { Mammalian Gene } \\
\text { Collection to isolate large } \\
\text { numbers of cDNA clones }\end{array}$ \\
\hline 400.0 & L. Stubbs & $\begin{array}{l}\text { Develop a mouse mutant } \\
\text { resource to link human } \\
\text { genes to health-related } \\
\text { functions }\end{array}$ \\
\hline 643.0 & L. Stubbs & $\begin{array}{l}\text { Characterization of a } \\
\text { neighboring region of } \\
\text { HSA19q13.4 which also } \\
\text { contains imprinted genes, } \\
\text { and study the evolutionary } \\
\text { history of the region by } \\
\text { comparative analysis of } \\
\text { genomic sequence in } \\
\text { human, mouse, rat, and } \\
\text { cow. }\end{array}$ \\
\hline 145.0 & L. Stubbs & $\begin{array}{l}\text { Completion of clone maps } \\
\text { for "difficult regions" of } \\
\text { HSA19 and other } \\
\text { DOE/JGI sequencing } \\
\text { targets }\end{array}$ \\
\hline 540.0 & M. Thelen & $\begin{array}{l}\text { Identify and characterize } \\
\text { novel genes and their } \\
\text { protein products that are } \\
\text { predicted to function in } \\
\text { DNA damage-response } \\
\text { pathways in mammalian } \\
\text { cells. }\end{array}$ \\
\hline 250.0 & K. Fidelis & $\begin{array}{l}\text { Advance the } \\
\text { computational approaches } \\
\text { to the structural and } \\
\text { functional studies to the } \\
\text { sequences performed by } \\
\text { the human genome project }\end{array}$ \\
\hline
\end{tabular}




\begin{tabular}{|r|l|l|}
\hline 63.0 & L. Ashworth & $\begin{array}{l}\text { Support for scientific } \\
\text { input into the design, } \\
\text { development and } \\
\text { implementation of both } \\
\text { the materials development } \\
\text { and educational modules } \\
\text { of the Einstein Institute } \\
\text { for Science Health and the } \\
\text { Courts (EINSHAC) } \\
\text { program }\end{array}$ \\
\hline 655.0 & P. Chain & $\begin{array}{l}\text { Finishing and analysis of } \\
\text { the Nostoc punctiforme } \\
\text { genome }\end{array}$ \\
\hline 225.0 & K. Turteltaub & $\begin{array}{l}\text { DNA sequencing for } \\
\text { biothreat reductions }\end{array}$ \\
\hline $\mathbf{1 6 , 8 4 6 . 5}$ & TOTAL & $\begin{array}{l}\text { Develop unique } \\
\text { methodology for the } \\
\text { analysis of a long-lived } \\
\text { isotope of beryllium, } \\
\text { beryllium-10 (Be-10), to } \\
\text { apply it to understanding } \\
\text { beryllium dosimetry and } \\
\text { to help determine the } \\
\text { cellular and molecular } \\
\text { mechanisms responsible } \\
\text { for beryllium disease }\end{array}$ \\
\hline
\end{tabular}

DOE (ASCR):

Support (K\$) Principal Investigator Objective

\begin{tabular}{|c|l|l|}
\hline 447.0 & M. Colvin & $\begin{array}{l}\text { Initiate research to } \\
\text { improve the understanding } \\
\text { of bacterial } \\
\text { multicomponent protein } \\
\text { machines through the use } \\
\text { of advanced molecular } \\
\text { simulation methods on } \\
\text { Terascale computers }\end{array}$ \\
\hline 447.0 & TOTAL & \\
\hline
\end{tabular}


DOE (Office of Non-Proliferation and National Security):

Support (K\$) Principal Investigator

Objective

\begin{tabular}{|c|c|c|}
\hline 543.2 & R. Balhorn & Toxins \\
\hline 776.0 & P. McCready & Instrument Interface \\
\hline $1,600.8$ & P. McCready & Basis Field Lab \\
\hline $5,082.8$ & P. McCready & Basis Special Task \\
\hline 291.0 & P. McCready & FastTrack APDS \\
\hline 330.6 & P. McCready & Multiplex Taqman \\
\hline $1,470.1$ & P. McCready & $\begin{array}{l}\text { Accelerated } \\
\text { ImmunoAssays }\end{array}$ \\
\hline 680.7 & P. McCready & Viruses \\
\hline 327.4 & P. McCready & $\begin{array}{l}\text { Sequencing Viral } \\
\text { Pathogens }\end{array}$ \\
\hline 792.5 & E. Garcia & BioInformatics \\
\hline 485.0 & G. Andersen & Signatures Development \\
\hline 388.0 & G. Andersen & Environmental \\
\hline 577.2 & G. Andersen & Microbial Background \\
\hline 145.5 & R. Langlois & \\
\hline 950.6 & R. Langlois & Assays \\
\hline 194.0 & B. Weinstein & BioForensics \\
\hline 630.5 & B. Weinstein & BDAP \\
\hline 149.9 & B. Weinstein & $\begin{array}{l}\text { Basis Program } \\
\text { Management }\end{array}$ \\
\hline 727.5 & T. Slezak & $\begin{array}{l}\text { BioFoundations } \\
\text { Informatics }\end{array}$ \\
\hline 291.0 & T. Slezak & Hardware Informatics \\
\hline $16,434.3$ & TOTAL & \\
\hline
\end{tabular}


LLNL (Laboratory Directed Research and Development):

Support (K\$) Principal Investigator

Objective

\begin{tabular}{|c|c|c|}
\hline 187.5 & M. Colvin & $\begin{array}{l}\text { New Approaches to } \\
\text { Quantum Computing } \\
\text { using Nuclear Magnetic } \\
\text { Resonance Spectroscopy }\end{array}$ \\
\hline 163.8 & A. Zemla & $\begin{array}{l}\text { Automated 3D Protein } \\
\text { Structure Prediction Based } \\
\text { on Sesitive-Sequence } \\
\text { Homology Identification }\end{array}$ \\
\hline $1,701.1$ & P. Fitch & $\begin{array}{l}\text { Identify and characterize } \\
\text { genes and proteins } \\
\text { responsible for virulence } \\
\text { and to develop a model of } \\
\text { the virulence mechanisms } \\
\text { of spcific bacterial } \\
\text { pathogens }\end{array}$ \\
\hline 700.0 & M. Colvin & $\begin{array}{l}\text { Exploit unique LLNL } \\
\text { expertise to achieve major } \\
\text { scientific advancements in } \\
\text { a series of biological } \\
\text { problems }\end{array}$ \\
\hline 367.3 & M. Coleman & $\begin{array}{l}\text { Develop novel } \\
\text { technologies for protein } \\
\text { expression and functional } \\
\text { analysis, expression, and } \\
\text { solubility optimization, } \\
\text { and crystallization }\end{array}$ \\
\hline 255.8 & L. Stubbs & $\begin{array}{l}\text { Establish new technical } \\
\text { foundations of a basic } \\
\text { program in regulatory } \\
\text { biology }\end{array}$ \\
\hline 54.4 & E. Garcia & Multiscale M \\
\hline 148.0 & K. Turteltaub & $\begin{array}{l}\text { Develop an approach that } \\
\text { will rapidly lead to assays } \\
\text { to detect protein and } \\
\text { metabolite signatures that } \\
\text { will identify a BW threat } \\
\text { agent in a variety of } \\
\text { situations }\end{array}$ \\
\hline 74.0 & P. Agron & $\begin{array}{l}\text { Identify genes encoding } \\
\text { secreted proteins in the } \\
\text { plague bacterium Yersinia } \\
\text { pestis }\end{array}$ \\
\hline
\end{tabular}




\begin{tabular}{|c|c|c|}
\hline 94.6 & I. Jones & $\begin{array}{l}\text { Develop metrics that } \\
\text { relate DNA repair gene } \\
\text { genotypes to DNA } \\
\text { capacity phenotypes }\end{array}$ \\
\hline 35.0 & R. Balhorn & Gard Collaboration \\
\hline 65.4 & M. Cosman & Shields Collaboration \\
\hline 36.9 & M. Corzett & Hollars Collaboration \\
\hline 89.8 & V. Motin & $\begin{array}{l}\text { Establish an important } \\
\text { connection between } \\
\text { plague and anthrax, } \\
\text { infectious agents which } \\
\text { have become an } \\
\text { increasing concern for } \\
\text { national security }\end{array}$ \\
\hline 120.0 & C. Prange & $\begin{array}{l}\text { Make available to the } \\
\text { microbial research } \\
\text { community flexible, } \\
\text { clone-based resources that } \\
\text { will aid in functional } \\
\text { studies of the microbe of } \\
\text { interest }\end{array}$ \\
\hline 157.5 & R. Balhorn & $\begin{array}{l}\text { Develop the methodology } \\
\text { needed to synthesize High } \\
\text { Affinity Ligands (HALs) - } \\
\text { small organic molecules } \\
\text { that function like synthetic } \\
\text { antibodies and bind to } \\
\text { specific biological targets } \\
\text { with high affinity and } \\
\text { specificity }\end{array}$ \\
\hline 126.4 & P. Chain & $\begin{array}{l}\text { Indentify and characterize } \\
\text { virulence candidate genes } \\
\text { in Francisella tularensis, } \\
\text { the causative agent of } \\
\text { tularemia }\end{array}$ \\
\hline 75.0 & M. Bennett & $\begin{array}{l}\text { Determine how PhIP and } \\
\text { Flor-Essence@ exposure } \\
\text { alter cell growth pathways } \\
\text { in the human MCF-7 } \\
\text { breast cancer cell line } \\
\text { using functional cell } \\
\text { proliferation and reporter } \\
\text { assays in combination } \\
\text { with new macroarray } \\
\text { technology }\end{array}$ \\
\hline
\end{tabular}




\begin{tabular}{|r|c|l|}
\hline 75.0 & A. Christian & $\begin{array}{l}\text { Produce a high-throughput } \\
\text { microenvironment in } \\
\text { which individual cells can } \\
\text { be studied }\end{array}$ \\
\hline $\mathbf{4 , 5 2 7 . 4}$ & TOTAL & \\
\hline
\end{tabular}

LLNL (General and Administrative): Support (K\$) Principal Investigator Objective

\begin{tabular}{|c|l|l|}
\hline 219.0 & M. Mendelsohn & Melanoma Investigation \\
& & Objective: To provide \\
& funds for operation of \\
& LLNL task force on \\
& & melanoma and to asess \\
& & and monitor increase \\
& & incidence of melanoma \\
& diagnosis among \\
& & \\
\hline 219.0 & TOTAL & \\
\hline
\end{tabular}

